\title{
A Rule of Reason Decision Model After Sylvania*
}

\author{
Eugene F. Zelek, Jr. $\dagger$ \\ Louis W. Stern†t \\ Thomas W. Dunfeett†
}

Writing for the Supreme Court of twenty years ago in Northern Pacific Railway v. United States, ${ }^{1}$ Justice Black praised "per se" rules as sources of economy and predictability in the administration of section 1 of the Sherman Act. $^{2}$ He characterized economic inquiry in antitrust cases as "often wholly fruitless," while statimg that rules of per se illegality not only avoid inost of this "incredibly complicated and prolonged" analysis, but also provide inore certainty to those concerned. ${ }^{3}$ Later, Justice Marshall expressed the Court's reluctance to "ramble through the wilds of economic theory" in United States v. Topco Associates, Inc. ${ }^{4}$ notimg that "courts are of limited utility in examining difficult economic problems." In laying down a per se rule, the majority stated that the judiciary's "inability to weigh . . . destruction of compe-

* Copyright 1979, Eugene F. Zelek, Jr., Louis W. Stern, and Thomas W. Dunfee.

$\dagger$ B.S. 1974, University of Illinois; M.M., J.D. 1978, Northwestern University; Meniber, Illinois Bar.

if A. Montgomery Ward Professor and Chairman of the Department of Marketing, J.L. Kellogg Graduate School of Management, Northwestern University; A.B. 1957, Harvard College; M.B.A. 1959, University of Pennsylvania; Ph.D. 1962, Northwestern University.

ti† Professor and Chairman of the Department of Legal Studies and the Public Management Unit, The Wharton School, University of Pennsylvania; A.B. 1963, Marshall University; J.D. 1966, L.L.M. 1969, New York Umiversity; Member, West Virginia Bar.

1. 356 U.S. 1 (1958).

2. Section 1 of the Sherman Act states: "Every contract, combimation . . . or conspiracy, in restraint of trade or commerce aunong the several States, or with foreign nations, is hereby declared to be illegal ...."15 U.S.C. \& 1 (1976).

According to the Supreme Court in National Soc'y of Professional Eng'rs. v. United States, 435 U.S. 679,692 (1978),

There are . . two complenientary categories of antitrust analysis. In the first category are agreements whose nature and necessary effect are so plainly anticompetitive that no elaborate study of the indnstry is needed to establish their illegality-they are "illegal per se"-in the second category are agreements whose competitive effect can only be evaluated by analyzing the facts peculiar to the business, the history of the restraint, and the reasons why it was imposed.

See Broadcast Music, Inc., v. Columbia Broadcasting Sys., Inc., 441 U.S. 1, 7-8 (1979).

3. 356 U.S. at 5 .

4. 405 U.S. 596,609 n.10 (1972).

5. Id. at 609 . 
tition in one sector of the economy agamst promotion of competition $\mathrm{m}$ another sector" is a key factor in the formulation of such rules. ${ }^{6}$ Overall, the Court felt that it was "ill-equipped and ill-situated for such decisionmaking."

Nonetheless, in Continental T.V., Inc. v. GTE Sylvania Inc. ${ }^{8}$ the Supreme Court returned to the rnle of reason ${ }^{9}$ for determining the legality of nonprice vertical restraints ${ }^{10}$-a standard which requires precisely the sort of economic investigation and balancing that per se rules seek to avoid. ${ }^{11}$ At the same time, neither Sylvania nor previous decisions offer inuch practical guidance to lawyers who must advise clients or to judges who inust decide cases under the rule of reason, leaving the question of what analytical methods are appropriate largely unresolved. ${ }^{12}$

This Article proposes a decision model to assist the bench and bar in the difficult economic inquiry required by Sylvania. Part I examines
6. Id. at 609-10.
7. Id. at 611 .
8. 433 U.S. 36 (1977).
9. The Court described the rule as follows:

Section 1 prohibits "[e]very contract, combination ... . or conspiracy, in restraint of trade or commerce." Since the early years of this century a judicial gloss on the statutory language has established the "rule of reason" as the prevailing standard of analysis. . . . Under this rule, the factfinder weighs all of the circuinstances of a case in deciding whether a restrictive practice should be prohibited as imposing an unreasonable restraint on competition.

Id. at 49-50 (citation and footnote omitted).

10. See text accompanymg note 18 infra.

11. Shortly after Sylvania, however, in lllinois Brick Co. v. Illinois, 431 U.S. 720 (1977), the economic complexity rationale resurfaced in an entirely different context to deny indirect purchasers' standing to sue under the antitrust laws. See Dunfee, Privity in Antitrust: Illinois Brick Co.v. Illinois, 16 AM. Bus. L.J. I07, 112-15 (1978).

12. Courts usually have been content with Justice Brandeis' well-known characterization of the rule of reason:

The true test of legality is whether the restraint imposed is such as merely regulates and perhaps thereby promotes competition or whether it is such as may suppress or even destroy competition. To determine that question the court must ordimarily consider the facts peculiar to the business to which the restraint is applied; its condition before and after the restraint was imposed; the nature of the restraint and its effect, actual or probable. The history of the restramt, the evil believed to exist, the reason for adopting the particular remedy, the purpose or end sought to be attained, are all relevant facts.

Chicago Bd. of Trade v. United States, 246 U.S. 231, 238 (1918). See, e.g., Continental T.V., Inc. v. GTE Sylvania Inc., 433 U.S. at 49 n.15.

However, this catalog of relevant considerations settles little more than the potcntial expansiveness of an inquiry under the rule. Guided primarily by the readily administrable per se rules, the courts have not articulated a workable legal standard to be applied in rule of reason cases. See ABA ANTitrust Section, Vertical Restrictions Limiting Intrabrand Competition 54 (Monograph No. 2, 1977) [heremafter cited at ABA MonograpH]; Pitofsky, The Sylvania Case: Antitrust Analysis of Non-price Vertical Restrictions, 78 Colum. L. Rev. 1, 34 (1978); Posner, The Rule of Reason and the Economic Approach: Reflections on the Sylvaria Decision, $45 \mathrm{U}$. CHI. L. REv. 1, 13-16 (1977); The Supreme Court, 1976 Term, 91 HARv. L. Rev. 231, 238-39 (1977) [hereinafter cited as The Supreme Court]. See also Kestenbaum v. Falstaff Brewing Corp., 575 F.2d 564, 570 (5th Cir.), cert. denied, 440 U.S. 909 (1978). 
the different types of vertical restrictions and the reasons why they are imposed, and considers the case law through Sylvania. Part II then outlines a five-step framework modeled on the principles laid down in Sylvania and other cases for applying the rule of reason to territorial and customer restrictions. ${ }^{13}$

\section{Vertical Restraints ON COMPETITION}

\section{A. The Business Context}

The long-tern viability of a supphier depends on the ability of its distribution system to compete effectively with the systems of rival firms. ${ }^{14}$ For this reason, a suppher typically seeks to present a united front against supphers of competing brands by exercising as inuch control over its distribution channels as possible. ${ }^{15}$

A supplier can achieve complete control by integrating forward to assume ownership of its distribution channels. Where integration is either inefficient or financially infeasible,${ }^{16}$ a number of alternative strategies exist. ${ }^{17}$. Foremost is the imposition of vertical restrictionsrestrictions imposed by agreement among firms or individuals at successive stages of distribution, such as contracts between a manufacturer and a distributor or dealer. ${ }^{18}$

13. See notes 25-27 and accompanying text infra.

14. L. Stern \& A. El-Ansary, Marketing Channels 6 (1977).

15. Each distribution system is composed of at least one "marketmg channel," which is defined as the "set of interdependent institutions and agencies involved with the task of moving anything of value from its point of conception, extraction, or production to points of consumption." Id. at 4. Thus, a hypothetical manufacturer's distribution systein could be coinprised of several channels involving the movement of goods froin the manufacturer (1) directly to endusers, (2) through wholesalers to end-users, and (3) through wholesalers and retailers to end-users. Of course, inany more channels and channel configurations are possible, often operating concurrently within the same distribution system.

To simplify discussion, the term "supplier" will refer to the firm on the selling side of the market, while "distributor" will refer to the reseller-buyer. See generally Preston, Restrictive Distribution Arrangements: Economic Analysis and Public Policy Standards, 30 L. \& CoNTEMP. PROB. 506, 507 n.4 (1968).

16. Significant diseconomies may discourage vertical integration:

First, distribution is a relatively low-profit activity; if a supplier can obtain the desired degree of control without assuming full investment responsibility, he may be able to employ his capital inore profitably elsewhere. Second, distribution is typically a inultiproduct activity, with the product mix of distributors substantially different from that of any one suppher; vertical mtegration under these circumstances involves a substantial broadening of a supplier's product responsibility as well as his functional role. Finally, the local managerial problems and personal service content of distribution discourage supphers from integrating forward when other alternatives are available.

Preston, supra note 15, at 512 (footnotes omitted).

17. See L. STERn \& A. El-ANSARY, supra note 14, at 276-316, 350-431. See also P. Kotler, Marketing Management: Analysis, Planning and Control 275-302 (3d ed. 1976).

18. Horizontal restrictions, in contrast, usually involve competitors or those economic enti- 
Vertical restrictions are often designed to reduce "intrabrand" coinpetition-coinpetition between distributors of the same brand. ${ }^{19}$ The rationale is that by protecting its distributors from competition ainong themselves, thie supplier will improve their effectiveness agamst distributors of otler brands. ${ }^{20}$ More specifically, the supplier offers this protection as an incentive or a quid pro quo for such distributor activities as point-of-sale promotion, repairs, and customer service, ${ }^{21}$ all of which a distributor might otherwise be unwilling to provide because of the possibility of "free riders."22

Vertical restraints fall into four general classifications, involving restrictions on prices, ${ }^{23}$ products, ${ }^{24}$ customers, and territories. This Ar-

ties at the same level in the distribution cham. United States v. Arnold, Schwinn \& Co., 388 U.S. 365, 378-79 (1976); United States v. Sealy, Inc., 388 U.S. 350, 352-54 (1967). Although it is often important fronı an antitrust point of view to distinguish these types, such categorization is not always an easy matter. See notes 75-79 and accompanying text infra.

19. Competition among sellers of different brands is referred to as "interbrand competition." Continental T.V., Inc. v. GTE Sylvania Inc., 433 U.S. at 52 n.19; L. STERN \& A. EL-ANSARY, supra note 14, at 318, 326; ABA MONOGRAPH, supra note 12, at 3 n.4.

20. Stern, Agodo, \& Firat, Territorial Restrictions in Distribution: A Case Analysis, $40 \mathrm{~J}$. MARKETING 69 (1976). Another motive on the part of a supplier in establishing territorial boundaries might be that it wishes to retain control over the cliannel by assuring that no distributor or group of distributors become too powerful. If a distributor were permitted to expand freely its niarket outreach, it might amass such a large amount of sales that it would be able to dictate terms to the supplier rather than vice versa. Id. at 70 .

Of course, distributors may have their own motives for supporting the imposition of vertical restraints which may not match those of the supplier. In fact, the supplier can become the pawn of cartelizing distributors which desire to use vertical restrictions to administer their conspiracy. See United States v. General Motors Corp., 384 U.S. 127 (1966).

21. See F. Scherer, Industrial Market Structure and Economic Performance 509 (1970); Denger, Vertical Restrictions: The Impact of Sylvania, 46 ANTiTRust L.J. 908, 910 (1978); Posner, supra note 12, at 4; Preston, supra note 15, at 511; Strasser, Vertical Territorial Restraints After Sylvania: A Policy Analysis and Proposed New Rule, 1977 Duke L.J. 775, 794-830; Note, A Proposed Rule of Reason Analysis for Restrictions on Distribution, 47 FoRdHAM L. REv. 527, 53742 (1978).

22. R. Posner, Antitrust Law: AN Economic Perspective 149 (1976). See nole 163 and accompanying text infra.

23. Also known as "resale price maintenance" or "vertical price fixing," this restraint limits distributors in their pricing flexibility and, therefore, may severely impinge on this primary aspect of competition. It is generally cousidered per se illegal under $\S 1$ of the Sherunan Act. See notes 80-89 and accompanying text infra.

24. Several restraimts can be listed under this lreading, includimg "tying" and "exclusive dealing." Broadly speaking, tying by the supplier is the practice of conditiouring the sale of a good or service to a distributor on its purcliase of another good or service. Exclusive dealing consists of prohibiting a distributor from selling the goods or services of competing suppliers as a condition of doing busimess with a particular supplier. These restraints can inpair competition among distributors and suppliers by foreclosing access to the market. See Preston, supra note 15, at 507-08. For a discussion of the applicable legal standards, see Tampa Elec. Co. v. Nashville Coal Co., 365 U.S. 320 (1961) (exclusive dealing); Northern Pac. Ry. v. United States, 356 U.S. 1 (1958) (tying); Times-Picayune Publishing Co. v. United States, 345 U.S. 594 (1953) (tying); Standard Oil Co. v. United States, 337 U.S. 293 (1949) (exclusive dealing). 
ticle examines only the latter two categories. ${ }^{25}$ A customer restriction prohibits a distributor from selling to specific customers or classes of customers regardless of their location. ${ }^{26}$ In contrast, a territorial restriction either prevents or discourages a distributor from selling outside a particular area. ${ }^{27}$

The nature and restrictiveness of the customer and territorial restraints chosen by the suppher are a function of the supplier's needs and its bargaining power with distributors. The most restrictive are those restraints intended completely to foreclose intrabrand competition. Custoiner restramts can achieve this by giving each distributor a "monopoly" in the suppher's product within its assigned class of customers. ${ }^{28}$ Similarly, absolute confinement of distributor sales to particular territories can preclude intrabrand rivalry, especially when this restriction is coupled with the supplier's practice of awarding exclusive distributorships in those areas. ${ }^{29}$ Even the "lesser" territorial restraints, which taken mdividually may only inhibit imtrabrand competition, ${ }^{30}$

25. Price restrictions are not discussed in terms of the rule of reason because the Sylvania Court explicitly confined its holding to nonprice vertical restraints while reaffirming the per se illegality of those involving price. See note 56 and accompanying text infra. Despite their nonprice nature, tying and exclusive dealing are also beyond the scope of this Article due to the fact that, unlike customer and territorial restrictions, they necessarily result im some degree of inarket foreclosure at the interbrand level. Moreover, Sylvania was a $\S 1$ Sherman Act case, while tymg and exclusive dealing may be challenged either under $\S 1$ or the somewhat different standards of $\S 3$ of the Clayton Act, 15 U.S.C. $\$ 14$ (1976).

26. Note, Restricted Channels of Distribution Under the Sherman Act, 75 HARv. L. REv. 795, 796 (1962) [hereinafter cited as Restricted Channels]. For example, in White Motor Co.v. United States, 372 U.S. 253, 257 (1963), a truck manufacturer reserved national accounts, fleet accounts, and government busmess for itself.

27. See notes 29-31 infra. See also Restricted Channels, supra note 26, at 796.

28. See Comanor, Vertical Territorial and Customer Restrictions: White Motor and Its Aftermath, 81 HARv. L. REv. 1419, 1422 (1968).

29. Also known as granting an "exclusive franchise," this practice involves the supplier's refusal to sell to anyone else in a particular area. See Restricted Channels, supra note 26, at 796. It is virtually per se legal due to judicial recognition of the seller's right to choose the buyers with which it will deal in the absence of monopolistic purpose or anticompetitive effect. See United States v. Amold, Schwinn \& Co., 388 U.S. at 376; Uinted States v. Colgate \& Co., 250 U.S. 300, 307 (1919); Oreck Corp. v. Whirlpool Corp., 579 F.2d 126, 131 n.6, 133 (2d Cir.) (en banc), cert. denied, 439 U.S. 946 (1978); Packard Motor Car Co. v. Webster Motor Car Co., 243 F.2d 418, 420 (D.C. Cir), cert. denied, 355 U.S. 822 (1957); Louis, Vertical Distribution Restraints Under Schwinn and Sylvania: An Argument for the Continuing Use of a Partial Per Se Approach, 75 MicH. L. REv. 275, 286 (1976).

Absolute confinement coupled with an exclusive distributorship creates a territory which is "exclusive" or "closed," or what Pitofsky calls "airtight." Pitofsky, supra note 12, at 4 n.10. But see ABA MONOGRAPH, supra note 12, at $4 \mathrm{n} .9$, where assigned territories alone are referred to as exclusive. There is no real difference in these definitions as long as the supplier assigning the territory sells to no other distributor in that area as a matter of course.

30. These restrictions include areas of primary responsibility, profit passover arrangements, and location clauses. An area of primary responsibility requires the distributor to use its best cfforts to maintain effective distribution of the suppher's product in the assigned territory, but the distributor remains free to sell outside its area, and other distributors may sell in its territory. 
can be combined with exclusive distributorships to effectively eliminate it. $^{31}$

\section{B. Case Law Under Section 1 of the Sherman Act}

The competitive effects of customer and territorial restrictions are coinplex. Such restrictions may increase interbrand competition by allowing individual supphers to compete more effectively. They do so, however, only at the expense of some degree of intrabrand competition. From an antitrust perspective, this result may be somewhat troublesome: the law, unlike the supplier, is interested in protecting competition among all sellers, including sellers of the same brand. ${ }^{32}$

During the first sixty years of the Sherman Act, lower federal courts uplield vertical restrictions in the absence of price fixing or supplier nonopoly. ${ }^{33}$ Not until 1963 in White Motor Co. v. United States ${ }^{34}$ did the Supreme Court face the question of whether territorial and customer restramts untainted by price fixing are legal. ${ }^{35}$

In White Motor, the government cliallenged territorial restrictions under which distributors were allowed to sell only within assignied territories and customer restrictions that prohibited sales to government

ABA MONOGRAPH, supra note 12, at 3 n.6. A profit passover arrangement requires a distributor that sells outside its territory to compensate the distributor in whose territory the customer is located. Such compensation is ostensibly to reimburse the second distributor for its efforts to stimulate demand in its territory and for the cost of providing services upon which the first distributor would otherwise capitalize. Id. at 4 n.7. A location clause limits a distributor to sales from a specified site, allowing the distributor to sell to any customer who walks through its door. Id. at 3 n.5.

31. For example, exclusive distributorships can be protected by location clauses which may in fact confine a distributor to its own territory. As indicated in note 29 supra, the resulting exclusive territory can also be achieved by using absolute territorial confinement in place of the location clauses. See Sandura Co. v. FTC, 399 F.2d at 856; Louis, supra note 29, at 288 n.73. See also Louis, Vertical Distribution Restraints After Sylvania: A Postscript and Comment, 76 Mich. L. REv. 265, 275-77 (1977).

32. See United States v. Arnold, Schwinn \& Co., 388 U.S. at 382; Cernuto, Inc. v. Unitcd Cabinet Corp., 595 F.2d 164, 166 n.11 (3d Cir. 1979); Martin B. Glauser Dodge Co. v. Chrysler Corp., 570 F.2d 72, 82 (3d Cir. 1977), cert. denied, 436 U.S. 913 (1978); Sandura Co. v. FTC, 339 F.2d 847 (6th Cir. 1964).

33. See Pollock, Franchising, Customer Restrictions and Building a Better Mousetrap, 46 CHI. B. REC. 378, 381 (1965).

34. In 1944, the Supreme Court held that vertical restrictions are unlawful per se if they are an essential part of an overall price-fixing arrangement. United States v. Bausch \& Lomb Optical Co., 321 U.S. 707, 719-23 (1944). Four years later, the Justice Department stated its view that restrictions totally barring intrabrand competition were themselves per se violations. As a result, a number of consent decrees were obtained. ABA MONOGRAPH, supra note 12 , at $7 \& \mathrm{nn} .16-17$. 372 U.S. 253 (1963).

35. The district court had granted the government's motion for summary judgment on a theory of per se illegality with respect to the defendant's territorial and customer restrictions and resale price inaintenance. On appeal, the lower court's action on the price-fixing issue was not challenged, and the defendant argued that the price agreements were inerely "adjunct" to the other restraints. White Motor Co. v. United States, 372 U.S. at 257. Thus, the Court had only the issue of territorial and customer restrictions before it. 
agencies and other entities. The Supreme Court refused to establish a per se rule, notimg: "This is the first case involving a territorial restriction in a vertical arrangement; and we know too little of the actual impact of both that restriction and the one respecting custoiners to reach a conclusion on the . . . evidence before us." ${ }^{36}$ The Court remanded the case for a trial on the inerits, ${ }^{37}$ but the parties subsequently stipulated to a consent decree. ${ }^{38}$

Less than five years later, the Court responded in a much different fashion when the issue of customer and territorial restraints came before it again. In United States $v$. Arnold, Schwinn \& Co.${ }^{39}$ the defendant used three types of marketing arrangements: (1) sales to wholesale distributors that resold to franchised retailers; (2) consignment or agency arrangements with distributors that sold to retailers; and (3) direct shipments to franchised retailers with a commission paid to the distributor that had taken the order. ${ }^{40}$ On the wholesale level, customer and territorial restrictions limited distributor sales to Schwinn franchisees within exclusive distributor territories. At the same time, customer restraints and location clauses confined retail sales to consumers who came to specified retail outlets. ${ }^{41}$

In his opinion for the Court, Justice Fortas distinguished Schwinn's outright sales to distributors and dealers from its agency and consignment transactions. Arguing that to allow a supplier to control goods after a sale would violate the "ancient rule against restraints on alienation," $" 42$ he stated that

36. Id. at 261.

37. Id. at 264. According to the Court,

A vertical territorial limitation may or may not have [the] purpose or effect [of stiflimg competition]. We do not know enough of the economic and business stuff out of which these arrangements emerge to be certain. They may be too dangerous to sanction or they may be ... within the "rule of reason." We need to know more than we do about the actual imipact of these arrangements on competition to decide whether they . . . should be classified as per se violations of the Sherman Act.

Id. at 263 (citations omitted).

38. United States v. White Motor Co., 1964 Trade Cas. If 71,195 (N.D. Ohio 1964). The company agreed to abandon its territorial and customer restraints. After White Motor, two appellate courts upheld such restrictions under a rule of reason analysis. Sandura Co. v. FTC, 339 F.2d 847 (6th Cir. 1964); Snap-On Tools Corp. v. FTC, 321 F.2d 825 (7th Cir. 1963).

39. 388 U.S. 365 (1967). This case has received extensive treatment in the literature. For more detailed analysis than is possible here, see the sources listed in Sylvania, 433 U.S at 48 n.13, and in ABA MoNOGRAPH, supra note 12, at 9 n.24.

40. 388 U.S. at 370 . Schwinn also sold its bicycles through hardware jobbers and B.F. Goodrich stores, and these sales most resembled those to Schwinn distributors. B.F. Goodrich was originally a defendant in the case, but it negotiated a consent decree with the government before the case came to trial. Id. at 367 n.1.

41. Id. at 370-71.

42. Id. at 378-80. This aspect of the opinion has been heavily criticized as being wholly irrelevant to the concerns of the antitrust laws. See, e.g., Baker, Vertical Restraints in Times of Change: From White to Schwinn to Where?, 44 ANTrrRUST L.J. 537, 537-38 (1975); Pollock, The 
[o]nce the manufacturer has parted with title and risk, he has parted with dominion over the product, and his effort thereafter to restrict territory or persons to whom the product may be transferred-whether by explicit agreement or by silent combination or understanding with his vendee-is a per se violation of $\S 1$ of the Sherman Act. ${ }^{43}$

Thus, the Court adopted a per se rule that invalidated the restrictions imposed on distributors and dealers which liad assumed all indicia of ownership.

As for the nonsale transactions,

[w] here the manufacturer retains title, dominion, and risk with respect to the product and the position and function of the dealer in question are, $m$ fact, indistinguishable from those of an agent or salesmen of the inanufacturer, it is only if the impact of the confinement is "unreasonably" restrictive of competition that a violation of $\S 1$ results from such confinement, unencuinbered by culpable price fixing. ${ }^{44}$

Applying the rule of reason, the Court concluded that the customer and territorial restraints on distributors operating under the agency agreements were lawful. ${ }^{45}$

Widely criticized by scliolars ${ }^{46}$ and frequently distinguished by judges, ${ }^{47}$ Schwinn proved to be unpopular and confusing precedent. The law reinained unsettled for ten years until the Supreme Court brought it full circle in Continental T. V., Inc. v. GTE Sylvania Inc. ${ }^{48}$ by announcing a "return to the rule of reason that governed vertical restrictions prior to Schwinn."49 Calling Schwinn "an abrupt and largely

Schwinn Per Se Rule: The Case for Reconsideration, 44 ANTITRUST L.J. 557, 561-71 (1975). For additional citations, see ABA MONOGRAPH, supra note 12, at 10 n.25.

43. 388 U.S. at 382. Earher in its decision, the Court stated that "[u]nder the Sherman Act, it is unreasonable without more for a manufacturer to seek to restrict and confine areas or persons with whom an article may be traded after the manufacturer has parted with dommion over it." Id. at 279 (citations omitted).

44. Id. at 380 (citation omitted).

45. Id. at 380-82.

46. See Continental T.V., Inc. v. GTE Sylvania Inc., 433 U.S. at 47-48 \& n.13.

47. The Schwinn rule was applied as the Court stated it in a number of cases, but many courts "struggled to distinguish or limit Schwinn in ways that are a tribute to judicial mgenuity." Robinson, Recent Antitrust Developments: 1974, 75 CoLuM. L. REv. 243, 272 (1975). For an extensive review of Schwinn's progeny, see ABA MONOGRAPH, supra nole 12, at 10-20. At least one commentator predicted the confusion in this area after Schwinn. Pogue, Vertical Restrictions on Price, Territory and Customers-The Certainty of Uncertainty, 29 OH10 ST. L.J. 272, 289 (1968).

48. 433 U.S. 36 (1977).

A growing body of legal hiterature provides a more detailed analysis of this case than is necessary for the purposes of this Article. E.g., Maher, On the Path from White 10 Schwinn 10 Sylvania to . . . 82 DICK. L. REv. 433 (1978); Pollock, Antitrust, the Supreme Court, and the Spirit of 76, 72 Nw. U.L. REv. 631, 632-40 (1977); Note, Sylvania and Vertical Restraints on Distribution, 19 B.C.L. REv. 751 (1978); Note, Vertical Restrictions and the Distribution Process: $A$ Practical Review of Economics and the Rule of Reason after Sylvania, 38 LA. L. REv. 1022 (1978); Note, Antitrust-Vertical Restrictions-Rule of Reason, 1977 WIS. L. REV. 1240.

49. 433 U.S. at 59. 
unexplained departure from White Motor,"50 Justice Powell's opinion expressly overruled the Schwinn per se rule. ${ }^{51}$

At issue in Sylvania was the legality of a location clause used by a television set inanufacturer and imposed on its retail franchisees. ${ }^{52}$ Such clauses had come under judicial scrutiny both before and after Schwinn and had been found lawful under a rule of reason standard. ${ }^{53}$ In addition, lesser territorial restrictions, including location clauses, had been allowed as alternatives to prohibited territorial and customer restramts. ${ }^{54}$ By equating location clauses with the restraints in Schwinn, ${ }^{55}$ the Sylvania Court not only dispelled the presuinption of their less restrictive effect, but also brought other vertical restramts, except price maintenance, ${ }^{56}$ imto issue.

After establishing the scope of its inquiry, the Court criticized Schwinn's focus on transaction form as a misplaced effort to account for the fact that vertical restrictions can simultaneously produce intrabrand harm and interbrand benefit. ${ }^{57}$ Referring to interbrand com-

50. Id. at 47.

51. Id. at 58. 38.

52. There were no other restraints present, nor were there exclusive distributorships. Id. at

53. Before Schwinn, Boro Hall Corp. v. General Motors Corp., 124 F.2d 822, 823-24 (2d Cir. 1942), cert. denied, 317 U.S. 695 (1943), upheld the reasonableness of location clauses. After Schwinn, several courts distinguished this restraint from the more ambitious customer and territorial restrictious in Schwinn and continued to approve it under a rule of reason analysis. E.g., Salco Corp. v. General Motors Corp., 517 F.2d 567, 575-76 (10th Cir. 1975); Sheldon Pontiac v. General Motors Corp., 418 F. Supp. 1024, 1036 (D.N.J. 1976), affd without opinion, 566 F.2d 1170 (3d Cir. 1977); Kaiser v. General Motors Corp., 396 F. Supp. 33, $39-41$ (E.D. Pa. 1975), affd without opinion, 530 F.2d 964 (3d Cir. 1976). However, the Supreme Court had "never given plenary consideration to the question of the proper antitrust analysis of location restrictions." 433 U.S. at 42 n.11. Cf. United States v. Geueral Motors Corp., 384 U.S. 127, 139-40 (1966) (Court refusal to consider their validity).

54. Although Schwinn was forced to give up its territorial and customer restrictions, the district court approved location clauses and areas of primary responsibility on remand. United States v. Arnold, Schwinn \& Co., 291 F. Supp. 564, $565-66$ (N.D. Ill. 1968). Accord, United States v. Topco Assocs., Inc., 1973-1 Trade Cas. I74,391 (N.D. Ill.), modified, 1973-1 Trade Cas. I1 74,485 (N.D. Ill.), affd mem., 414 U.S. 801 (1973).

55. According to the opinion:

In intent and competitive impact, the retail-customer restriction in Schwinn is indistinguishable from the location restriction in the present case. In both cases the restrictions limited the freedon of the retailer to dispose of the purchased products as he desired. The fact that one restriction was addressed to territory and the other to customers is irrelevant to functional antitrust analysis and, indeed, to the language and broad thrust of the opinion in Schwinn.

433 U.S. at 46 (footnote omitted). But see id. at 60 (White, J., concurring).

Pitofsky argues that with this language, the Court "punped up Schwinn to its broadest possible reading, thereby producing an easy target to puncture and deflate." Pitofsky, supra note 12, at 8.

56. The majority noted that: "As in Schwinn, we are concerned here only with nonprice vertical restrictions. The per se illegality of price restrictions has been established firmly for many years and involves significantly different questions of analysis and policy." 433 U.S. at 51 n.18.

57. Id. at 52-57. 
petition as "the primary concern of antitrust law," 58 the majority noted that the significant potential for procompetitive impact at this level nuakes a per se rule inappropriate..$^{59}$ Thus, the Court held that nonprice vertical restraints inust be judged under the rule of reason by examining both their interbrand and intrabrand effects. ${ }^{60}$ At the same time, it left the door open to utilization of a per se rule in unspecified circuinstances. ${ }^{61}$

Sylvania teaches that vertical restrictions can be valuable tools to pronote effective interbrand competition in modern markets. A court inust therefore carefully scrutinize those restrictions to determine their effect on coinpetition in the particular business settings where they are eniployed. Sylvania failed, however, to provide details on how to apply the rule of reason. Instead, it confined its guidance to a reiteration of Justice Brandeis' oft-quoted description of the rule of reason, ${ }^{62}$ leaving unanswered the crucial questions of what effects are relevant and how they should be coinpared.

Relatively few courts have applied the rule of reason in section 1 Sherman Act cases, ${ }^{63}$ and fewer have analyzed vertical restraints under this standard. In those cases that followed White Motor but preceded the developinent of the per se rule in Schwinn, courts seemed to consider the factors histed in Brandeis' statement. They failed, however, to systenratically identify the relevant economic criteria and to integrate those criteria into an analytic structure. ${ }^{64}$

58. Id. at 52 n.19.

59. Early in its analysis, the Sylvania Court stated that "/p/er se rules of illegality are appropriate only when they relate to conduct that is manifestly anticompetitive." $I d$. at 49-50. Such conduct is defined as agreements or practices which have a "pernicious effect on competition and lack . . . any redeeming virtue." Id. at 50 (quoting Northern Pac. Ry. v. United States, 356 U.S. at 5). Applying these principles to the facts before it and to vertical restrictions in general, the Court rejected the per se rule. 433 U.S. at 57-58.

60. A number of post-Sylvania decisions have applied the rule of reason to nonprice restrictions. See, e.g., H \& B Equip. Co. v. International Harvester Co., 577 F.2d 239, 246 (5th Cir. 1978); General Beverage Sales Co. v. East-Side Winery, 568 F.2d 1147, 1153 (7th Cir. 1978); Adolph Coors Co. v. A \& S Wholesalers, lnc., 561 F.2d 807, 813-14 (10th Cir. 1977); Newberry v. Washington Post Co., 438 F. Supp. 471,474 (D.D.C. 1977).

61. According to the Court: "[W]e do not foreclose the possibility that particular applications of vertical restrictions might justify per se prohibition . . . ." 433 U.S. at 58.

62. Id. at 49 n.15 (quoting Chicago Bd. of Trade v. United States, 246 U.S. at 238). See note 12 supra.

63. Posner, supra note 12, at 14.

64. As the ABA's Antitrust Law Section has noted:

[T]hose few cases which have considered vertical distribution restraints under a rule of reason liave frequently quoted Mr. Justice Brandeis' classic expression of rule of reason, recounted general economic facts of the industry, reviewed the purposes of the restraint, and inade conclusions about the relative effects of the restriction on dampening intrabrand competition while promoting interbrand competition. These cases typically do not consider in depth such questions as relevant market, market power, product differentiation, ease of entry, or structural or behavioral indicators of competition or its absence. 
The remainder of this Article constructs a model to apply the rule of reason reestablished in Sylvania. Decision models are often too inechanistic and simphistic to be apphied to real situations. This model, lowever, seeks to be practical. It introduces no new criteria or ways to characterize structures and behavior; instead, it merely creates a logical and comprehensive framework in which to apply those criteria that long have been used satisfactorily. Further, this model expresses those criteria in general terms that will allow the judiciary adequate decisionmaking flexibility. ${ }^{65}$

II

\section{The Rule of Reason Decision Model}

\section{A. Step One: Identifying the Agreement}

Prior to scrutinizing a supplier's distribution practices under the rule of reason, a court inust decide whether those practices actually involve a "contract, combination . . . or conspiracy . . . ."66 That is, in order to apply the Slierman Act, the court must determine whether a restrictive agreement exists between the supplier and its distributors. If no such agreement can be shown, the fact that the supplier's distribution practices negatively affect competition is irrelevant for purposes of the Act.

In many cases this task will be trivial; the parties often memorialize terms of such restrictions in written agreements. In other cases, however, the evidence of an agreement and its terms may not be so clear. Courts must then examine the parties' conduct and the charac-

Nor do they contain a detailed consideration of the effect of the restraint on price, pro-

duction levels, product quality, service competition, etc.

ABA MONOGRAPH, supra note 12, at 54.

Although the ABA publication fails to cite any cases in support of this statement, it does cite one opinion as an exception to it. In American Motor Inns, Inc. v. Holiday Inns, Inc., 521 F.2d 1230, I246-53 (3d Cir. 1975), the court employed economic analysis as part of its application of the rule of reason to an exclusive dealing arrangement considered under the Sherman Act.

After White Motor and before Sylvania, there were only two principal rule of reason decisions involving customer and territorial restrictions, Sandura Co. v. FTC, 339 F.2d 847 (6th Cir. 1964), and Snap-On Tools Corp. v. FTC, 321 F.2d 825 (7th Cir. 1963). Despite the fact that each court goes somewliat farther than the monograph's description, neither case sets out an analytical framework.

65. Since the decision model we propose simply describes a systenatic way of analyzing vertical restriction cases, the ordering of "steps" is not intended to suggest that judicial administration in application of the inodel involves a series of successive and discrete inquiries. Clearly, the practicalities attending the amassing and presentation of information will ultimately control the conduct of an actual case. Moreover, information needed at one stage of the analysis inay be useful at others as well. This may be particularly true with respect to the definition of relevant market; in a complex case, defining the relevant market nay be desirable, even necessary, at the identification stage.

66. 15 U.S.C. $\S 1$ (1976). 
teristics of the market to infer accord. ${ }^{67}$

In summary, if the restriction at issue is not the product of an agreement, the court should declare it valid and terminate the analysis. If the court finds that there was an accord, however, the anaylsis should proceed to Step Two.

\section{B. Step Two: Per Se Illegality of Horizontal Agreements and Vertical Price Fixing}

\section{Horizontal Agreements}

The Supreme Court has held that horizontal arrangementsagreements among competitors to divide markets, ${ }^{68}$ fix prices, ${ }^{69}$ or cut off competitors ${ }^{70}$-are per se violations of section 1 of the Slierman Act. Several commentators have suggested that the Sylvania Court's decision to apply the rule of reason to nonprice vertical restraints extends at least to certaim restramts that have both vertical and horizontal aspects. ${ }^{71}$ However, the Court implicitly rejected this position by distinguishing United States v. Topco Associates, Inc. ${ }^{72}$ a case in which such a mixed scheme of restraints was held per se illegal. ${ }^{73}$ The Court's treatment of Topco confirms the behef that lorizontal arrangements

67. The cases in which the Court has allowed agreenent to be inferred involve horizontal restraints and thus may not be wholly applicable to vertical behavior. See, e.g., Interstate Circuit, Inc. v. United States, 306 U.S. 208 (1939). Nonetheless, because the consequences of finding vertical agreenents are not necessarily as severe as in the case of horizontal agreement-vertical agreements are not per se illegal-such inferences are appropriate.

68. United States v. Topco Assocs., Inc., 405 U.S. at 608 n.9; Timken Roller Bearing Co. v. United States, 341 U.S. 593, 598 (1951); Addyston Pipe \& Steel Co. v. United States, 175 U.S. 211, 240-41 (1899).

69. United States v. Socony-Vacuuin Oil Co., 310 U.S. 150, 223-26 \& n.59 (1940); United States v. Trenton Potteries Co., 273 U.S. 392, 397-98 (1927).

70. United States v. General Motors Corp., 384 U.S. at 145-46; Klor's Inc. v. Broadway-Hale Stores, Inc., 359 U.S. 207, 212 (1959).

71. Professor Slater argues that "[t]o avoid the anomalous result of per se illegality along with pro-competitive effect," the rule of reason approach in Sylvania should be used in mixed cases like Topco where there is no price fixing. Address by Professor Paul E. Slater, Vertical Territorial Restraints: Schwinn Reconsidered (Oct. 12, 1977), reprinted in 2 The Sixteenth Annual Corporate Counsel Institute 1-19, at 1-12 (Northwestern University School of Law, 1977) (mimeo). See Handler, Changing Trends in Antitrust Doctrines: An Unprecedented Supreme Court Term-1977, 77 Colum. L. Rev. 979, 987 (1977); Posner, supra note 12, at 9.10; Weisberg, Continental TV v. GTE Sylvania: Implications for Horizontal as Well as Vertical Restraints on Distributors, 33 Bus. LAw. 757 (1978). See also United States v. Topco Assocs., Inc., 405 U.S. at 621-24 (Burger, C.J., dissenting); United States v. Sealy, Inc., 388 U.S. at 362 (Harlan, J., dissenting); United States v. Topco Assocs., Inc., 319 F. Supp. 1031, 1038-43 (N.D. Ill. 1970), rev'd, 405 U.S. 596 (1972); Note, Terrilorial and Customer Restrictions: A Trend Toward a Broader Rule of Reason, 40 GEo. WASH. L. REv. 125, $149-50$ (1971). See generaliy Louis, supra note 29, at 281.

72. 405 U.S. 596 (1972).

73. Id. at 606-12. See Bohling, A Simplified Rule of Reason for Vertical Restraints: Integrating Social Goals, Economic Analysis, and Sylvania, 64 IowA L. REv. 461, 509 (1979). For a postSylvania decision in a mixed case where Topco was not distinguished, see Ohio-Sealy Mattresis Mfg. Co. v. Sealy, Inc., 585 F.2d 821, 830-31 (7th Cir. 1978), cert. denied, 440 U.S. 930 (1979). 
unreasonably restrict competition. ${ }^{74}$

The Court recognized in Sylvania that it is often difficult to distinguish between horizontal and vertical arrangements. ${ }^{75}$ This difficulty is most likely to arise in two situations: (1) when it appears that distributors have combined to initiate restrictive agreements with their supphers; and (2) when a supphier is vertically integrated downstream so that it is coinpeting directly with the distributors with which it has restrictive agreeinents.

In the first situation, courts must look to intrabrand market structure and conduct-both before and after the restraints were imposedto determine whether the agreement is vertical or horizontal. For exainple, when the distributors own and control the supplier, a court may readily infer accord between the distributors. In Topco, the Court concentrated on the control that the members of a grocer's cooperative exercised in establishing territories for nnarketing the jointly branded products. ${ }^{76}$ In less obvious cases, however, judgments of illegality inay depend on inore attenuated chains of inferences.

In the second situation, courts may find the restrictions to be horizontal on the basis of the structural alignment of the parties. ${ }^{77}$ In soine cases, however, the history of the supplier's distribution practices may justify considering the restrictions vertical. For example, in Coca Cola Co. ${ }^{78}$ the Federal Trade Commission lield that the defendant did not engage in horizontal inarket allocation even though all of its bottlers, including company-owned units, operated in exclusive territories that the defendant assigned. This determination turned on the fact that when the restraints were originally imposed, they were clearly vertical; Coca Cola established the territories before it entered the bottling market. $^{79}$

If the court finds that the restriction is horizontal, it should immediately strike it down as per se unreasonable. If, however, the court concludes that the restriction is vertical, it should proceed with the analysis.

74. See Bohling, supra note 73, at 509; Restricted Channels, supra note 26 , at 800 . But see Broadcast Music, Inc. v. Columbia Broadcasting Sys., Inc., 441 U.S. 1 (1979) (horizontal agreement to be tested under the rule of reason).

75. 433 U.S. at 58 n. 28 .

76. 405 U.S. at 599-600. See Umited States v. Sealy, Inc., 388 U.S. at 352-53; United States v. Serta Assocs., Inc., 296 F. Supp. 1121, 1127-28 (N.D. Ill.), aff'd per curiam, 393 U.S. 534 (1969).

77. E.g., American Motor Inns, Inc., v. Holiday Inns, Inc., 521 F.2d 1230 (3d Cir. 1975). In this case, the court stated that a franchiser of motor hotels was guilty of horizontally allocating markets in violation of the Sherman Act because it owned and operated a number of franchises and blocked independent franchisees from competing with company-owned outlets. Id. at 125354.

78. 91 F.T.C. 517, appeal docketed, No. 78-1364 (D.C. Cir. 1978).

79. Id. at 611-14. 


\section{Vertical Price Fixing}

With few exceptions, courts have treated vertical price mamtenance arrangements as per se unlawful under the Sherman Act since $1911,^{80}$ based on the assumption that both horizontal and vertical price fixing have a ruinous effect on competition. ${ }^{81}$ Furthermore, when the per se rule is applied broadly, even the presence of price fixmg may cause otherwise-reasonable accompanying territorial restrictions to be invalidated ${ }^{82}$ This is true whether the price fixing is an integral part of the whole distribution $\operatorname{systein}^{83}$ or the territorial restraints were merely ancillary to the price scheme. ${ }^{84}$

In his concurring opinion in Sylvania, Justice White argued that the Court's economic approach to vertical arrangements requires that vertical price fixing be brought within the rule of reason. ${ }^{85}$ The majority rejected his argument, however, and exphicitly preserved the per se treatment of vertical price restrictions. ${ }^{86}$ It endorsed the view that vertical price inaintenance schemes are inherently more harmful to competition than are territorial restrictions: "[U]nlike nonprice restrictions, '[r]esale price mamtenance is not designed to, but almost mvariably does in fact, reduce price competition not only among sellers of the affected product, but quite as much between that product and compet-

80. Dr. Miles Medical Co. v. John D. Parke \& Sons, 220 U.S. 373 (1911), did not expressly apply a per se rule, but such a result may be inferred from its reasoning. Id. at 408. See also United States v. McKesson \& Robbins, Inc., 351 U.S. 305 (1955); United States v. Line Material Co., 333 U.S. 307 (1948); United States v. Bausch \& Lomb Optical Co., 321 U.S. 707 (1944).

The state statutory exceptions to this rule, known as "fair trade laws," lost their federal authorization as a result of the Consumer Goods Pricing Act of 1975, Pub. L. No. 94-145, §§ 2-3, 89 Stat. 801 (amending 15 U.S.C. $\S \S 1$, 45(a) (1970)). Court-created exceptions based on consignnuent sales, as in United States v. General Elec. Co., 272 U.S. 476 (1926), and on unilateral refusals to deal, as in United States v. Colgate \& Co., 250 U.S. 300 (1919), have been substantially eroded. See Albrecht v. Herald Co., 390 U.S. 145 (1968) (refusals to deal); Simpson v. Union Oil Co., 377 U.S. 13 (1964) (consignments); United States v. Parke, Davis \& Co., 326 U.S. 29 (1960) (refusals to deal).

81. See, e.g., United States v. Socony-Vacuum Oil Co., 310 U.S. 150, 224-26 \& n.59 (1940).

82. United States v. Arnold, Schwinn \& Co., 388 U.S. at 375-76. This result is entirely consistent with White Motor, as the Court there considered only territorial and customer restraints. See note 35 supra. The key concept here is the notion of accompaniment. The presence of vertical price fixmg with regard to one distributor, but not others, contaminates only the territorial and cnstouner restraints of that distributor. See Newberry v. Washington Post Co., 438 F. Supp. 471 (D.D.C. 1977).

83. United States v. Bausch \& Lomb Optical Co., 321 U.S. at 720.

84. White Motor Co. v. Umited States, 372 U.S. at 260; Copper Liquor, Inc. v. Adolph Coors Co., 506 F.2d 934, 938 (5th Cir. 1975); Pitchford Scientific Instruments Corp. v. Pepi, Inc., 435 F. Supp. 685, 689 (W.D. Pa. 1977).

85. According to Justice White, "The effect, if not the intention, of the Court's opinion is necessarily to call into question the firmly established per se rule against price restraints." 433 U.S. at 70 (White, J., concurring).

86. Id. at 51 n.18. 


\section{ing brands." "s87}

Thus, the traditional per se rule continues to control vertical price setting. The rule inay be subject to future limiting interpretations, ${ }^{88}$ but the courts will apply the existing per se standard to strike down a contractual or coercive arrangement that compels distributors to price at a specified level or within an established range. ${ }^{89}$

At this point, a court should invalidate an arrangement that evi-

87. Id. (quoting White Motor Co. v. United States, 372 U.S. 253, 268 (1963) (Brennan, J., concurring)).

There is a considerable difference of opinion as to how much the Court's analysis in Sylvania undermines the per se illegality of vertical price fixing despite its language to the contrary. Dismissing the Court's price/nonprice distinctions and relying on its economic emphasis, Professor Posner asserts his customary view that resale price maintenance should be subjected to the rule of reason, claiming that Dr. Miles and Albrecht are now "endangered precedents." Posner, supra note 12, at 7-13. Professor Pitofsky agrees that the theoretical justifications in Albrecht for a per se rule in maximum resale price-fixing situations have been jeopardized, but he contends that the disparate effect of minimum resale price inaintenance still warrants per se treatınent. Pitofsky, supra note 12 , at $14-17,32-33$ \& n.59.

88. The use of per se rules for vertical price fixing appears at first blush already to have been undercut somewhat in Eastern Scientific Co. v. Wild Heerbrugg Instruments, Inc., 572 F.2d 883 (Ist Cir.), cert. denied, 439 U.S. 833 (1978). In that case, a distributor was limited to Rhode Island, and it could price at any level within the state. However, all sales outside its territory had to be at or above list price. The district court instructed the jury on the per se theory, but the First Circuit reversed, holding that Sylvania mandated a rule of reason standard. The court reasoned that the maximum effect of the plan would be to limit sales to the set territories-a result that Sylvania explicitly holds should be tested under the rule of reason. $I d$. at 886 .

Notwithstanding Heerbrugg, courts still view arrangements involving price with suspicion, especially where more traditional price fixing may be involved. For example, in Cernuto, Inc. v. United Cabinet Corp., 595 F.2d 164 (3d Cir. 1979), the court held that the termination of the plaintiff distributor at the behest of another distributor could constitute a per se violation where such action was motivated by the plaintiff's discount selling.

At the same time, the Supreme Court has examined situations with price overtones more carefully and has applied the rule of reason rather than iminediately resorting to a per se label as in the past. Compare United States v. Socony-Vacuum Oil Co., 310 U.S. at 224-26 \& n.59 with Broadcast Music Inc. v. Columbia Broadcasting Sys., Inc., 441 U.S. 1 (1979) (blanket licensing) and National Soc'y of Professional Eng'rs v. United States, 435 U.S. 679 (1978) (bidding restrictions).

The idea that contractually imposed "partial" resale price nuaintenance is not per se illegal may be shocking to antitrust traditionalists. In fact, however, such a program may not have a significant negative effect on imtrabrand competition. In the Heerbrugg scheme, the existence of such an effect depends on the terms of the territorial restrictions, not the method of enforcing them. Indeed, as noted in the text accompanying notes 155-64 infra, territorial restrictions may make distributors more effective on the interbrand level--even when enforced by price restraints. A partial price maintenance plan will pose a threat to interbrand competition only if it is part of a comprehensive system of vertical price fixing enforced by coercion and wrongful termination. The issues involved in determining whether a partial price maintenance plan is harmful to coinpetition are appropriately dealt with at the factfinding stage of trial under a rule of reason standard.

This entire issue, however, may be rendered academic by Sylvania. After the reinstatement of the rule of reason, a supplier may contractually enforce territorial confinement and need not resort to the circuitous enforcement system used in Heerbrigg.

89. See, e.g., Simpson v. Union Oil Co., 377 U.S. 13 (1964); United States v. Parke, Davis \& Co., 362 U.S. 29 (1960); Cernuto Inc. v. United Cabimet Corp., 595 F.2d 164 (3d Cir. 1979); Sahn v. V-1 Oil Co., 402 F.2d 69 (10th Cir. 1968). 
dences a vertical establishment of price. If, however, there is no such evidence, the court slould continue on to Step Three.

\section{Step Three: Negative Impact on Intrabrand Competition}

If the restrictions include neither horizontal conspiracy nor price fixing, the next step is to determine whether they liave a negative impact on intrabrand competition. Such an impact is present when any restriction significantly inhibits a distributor of a particular brand in its attempts to win customers away froin other distributors of the saine brand. Theoretically, every vertical restraint may have soine negative impact on intrabrand competition. However, there is no need to burden the courts with those de minimus restrictions that do not have a materially adverse effect on intrabrand coinpetition in the context in which they operate.

The type of restraint may be a factor in determining its imtrabrand impact. For example, a distribution plan whicl requires only that each distributor devote its best efforts to a specific geographic area will probably reduce imtrabrand coinpetition very little. Under such a plan, as long as a distributor does not neglect its assigned area, it will reinain free to attempt to sell im other areas. Therefore, such a restraint may not appreciably reduce competition between distributors. ${ }^{90}$

The type of commodity offered may also be a factor. For example, location clauses will have a minimal impact on imtrabrand competition for goods and services that are expensive or highly individualized. ${ }^{91}$ Thus, a taxpayer's choice among several tax preparation franchisees in a given area will be influenced at least as inuch by his or her assessinent of the relative quality of their work as by convenience of location; the franchisees will continue to coinpete as vigorously as if they were not restricted to a given location. ${ }^{92}$

If the court concludes that substantial intrabrand coinpetition exists despite the restrictions, it should uphold them without further analysis. If, on the other hand, the impact on imtrabrand coinpetition is significant, the court should proceed to Step Four.

90. See generally Pitofsky, supra note 12, at 4-5.

91. See Restricted Channels, supra note 26, at 795.

92. Pitofsky, a hardliner on the issue of limiting vertical restrictions, agrees:

A nnanufacturer may designate five or ten distributors in each area and then inpose soine restraint such as a location clause or a restriction on sales to unauthorized distributors. Little or no intrabrand coinpetition is lost thereby, and it should not be necessary for a court to enter upon the exceedingly difficult and elusive inquiry into the supplier's purposes and market power. . . .

Pitofsky, supra note 12 , at 34 . 


\section{Step Four: Presumptively Illegal Restrictions}

If a distribution arrangement contains a nonprice vertical restriction and has a significant negative effect on intrabrand competition, the court should next determine whether to treat the restriction as presumptively illegal. The rationale for such a presumption is based on economy. There are circuinstances in which the probability that vertical restrictions will have procompetitive effects is so low that the arrangements would almost certainly fail under the detailed rule of reason analysis; in such circuinstances, it makes little sense to expend scarce judicial resources.

The Sylvania Court stated that such a situation formed the basis for applying a per se rule..$^{93}$ Although resolution of certam threshold factual issues before utilizing a per se standard is not unknown to antitrust law, ${ }^{94}$ perhaps such a rule is more accurately described here as what one commentator has called a "qualified per se rule"95 or what this Article refers to as a "rule of presumptive illegality." 96 The defendant may rebut this presuinption of illegality by showing that it is entitled to various defenses. ${ }^{97}$

93. See Continental T.V., Inc. v. GTE Sylvania Inc., 433 U.S. at 50 n.16. See also note 59 supra.

94. Threshold factual issues must often be proven in order to activate a per se rule. See Slater, supra note 71 . For instance, although tying agreements are generally considered per se illegal, the Sherman Act requires proof that the seller has economic power over the tying product and does a not insubstantial amount of its business in the tied product before the per se rule is available. See, e.g., Fortner Enterprises, Inc. v. United States Steel Corp., 394 U.S. 495, 499 (1969); Northern Pac. Ry. v. Umited States, 356 U.S. at 6. Similarly, group boycotts are also viewed as per se violations, but proof of anticompetitive intent is relevant which always leads to an examination of the marketplace before the rule can be applied. See, e.g., E.A. McQuade Tours, Inc. v. Consolidated Air Tour Manual Comm., 467 F.2d 178 (5th Cir. 1972); Joseph E. Seagram \& Sons, Inc. v. Hawaiian Oke \& Liquors, Ltd., 416 F.2d 71 (9th Cir. 1969).

95. Slater argues that this approach, while unannounced, has been applied for some time in one form or another as an intermediate alternative to both the rule of reason and the per se rule:

Many courts have never compartmentalized their antitrust decisions nearly as inuch as the two pronged doctrime would seem to require. Their analysis has often been incomplete under a full rule of reason, but too extensive for a strict per se rule. . . The lack of formal recognition has probably prevented this appoach froun obtaiming its full significance. The greatest importance of GTE Sylvania may turn out to be that it was a step towards that recognition.

Slater, supra note 71, at 1-13 (citing United States Steel Corp. v. Fortner Enterprises, Inc., 429 U.S. 610 (1977); United States v. Philadelphia Nat'l Bank, 374 U.S. 321 (1963); Fashion Origmators' Guild of America, Inc. v. FTC, 312 U.S. 457 (1941); Moore v. Jas. H. Matthews \& Co., 550 F.2d 1207 (9th Cir. 1977)).

96. This terminology was utilized in a seminal article on this subject, Baker, supra note 42, at $544-49$, and has been tentatively adopted by the Justice Department for its enforcement activity involving vertical restrictions, Address by Richard J. Favretto, Deputy Director of Operations, Antitrust Division, Department of Justice, Southwestern Legal Foundation Symposiun on Antitrust Law (May 12, 1978), reprinted in 5 TRADE REG. REP. (CCH) I 50,370 (1978) [hereinafter cited as Favretto]. See also Bohling, supra note 73, at 514-16.

97. Exceptions to per se rules have been utilized for soine time. Several tying cases have found that product quality considerations justify the use of what might otherwise be an illegal 
The presumption is triggered if the supplier imposing the restrictions is a core nember of a tightly knit oligopoly ${ }^{98}$ or otherwise possesses substantial market power. ${ }^{99}$ In these situations, interbrand competition can be improved only through erosion of inarket dominance-i.e., through improvement in the competitive position of less powerful suppliers. Because vertical restrictions miposed by the doininant firm or firms in an industry will only rarely (and obviously only accidentally) cause such a reallocation of market power, a presumption that these restrictions are illegal is appropriate.

The presuinption of illegality is also appropriate because intrabrand rivalry is likely to be the only competitive force where a firm or firms possess substantial market power. Although the antitrust laws value interbrand coinpetition more than imtrabrand competition, they are by no means unconcerned witl the latter. ${ }^{100}$ Where suppliers are essentially immune to price coinpetition from other supphers, coinpetition among distributors is inost miportant. ${ }^{101}$ The antitrust laws inust therefore ensure that such competition is not diminished.

Courts sliould use a structural analysis to determine whether the defendant supplier possesses sufficient inarket power, either alone or as part of an oligopolistic core, to warrant the presunption. This analysis begins by defining the relevant market in which the court is to evaluate market power. It then examines the following characteristics of the market in which the defendant competes: (1) the level of concentration in the industry; (2) the extent of product differentiation; and (3) the leight of barriers to entry in the market. ${ }^{102}$ Finally, it examines the

restraint. See, e.g., Dehydrating Process Co. v. A.O. Smith Corp., 292 F.2d 653 (1st Cir.), cert. denied, 368 U.S. 931 (1961); United States v. Jerrold Elec. Corp., 187 F. Supp. 545 (E.D. Pa. 1960), affd per curiam, 365 U.S. 567 (1961). In a post-Sylvania case, a Tenth Circuit panel reversed the lower court and held that the supplier's territorial and customer restrictions must be judged under the rule of reason, taking into account its quality preservation claims. Adolph Coors Co. v. A \& S Wholesalers, Inc., 561 F.2d 807, 813-14 (10th Cir. 1977).

98. For a definition of a tightly knit oligopoly, see notes $114-23$ and accompanying text infra.

99. Market power is broadly defined as an individual firm's abihity to affect price by varying output. Almost all firms have this ability, at least to some degree. F. SCHERER, supra note 21, at 10. We use the term "substantial narket power" to describe a situation in which a firm is large enough, relative to the industry in which it competes, to be considered either a member of an oligopolistic core or a "dominant" firm in an otherwise fragmented industry.

100. See Continental T.V., Inc. v. GTE Sylvania Inc., 433 U.S. at 51-59; United States v. Arnold, Schwinn \& Co., 388 U.S. at 382; Cernuto, Inc. v. United Cabinet Corp., 595 F.2d at 166 n.11 (3d Cir. 1979); Martin B. Glauser Dodge Co. v. Chrysler Corp., 570 F.2d at 82; Sandura Co. v. FTC, 339 F.2d 847, 858 (6th Cir. 1964).

101. See Favretto, supra note 96 . The absence of price competition among the distributors of all the inembers of an oligopolistic core may facilitate parallel pricing beliavior in the interbrand wholesale nuarket by increasing price certainty throughout the distribution process. Id.

102. An examination of the competitive claracteristics of the industry serves two purposes. First, it is obviously necessary in order to determine whether a tightly knit oligopoly exists. Second, if no such oligopoly exists, information about market conditions is necessary to assess the 
defendant supplier's position in the market to determine whether it is a core member of a tightly-knit oligopoly detected in the previous inquiry or, if no sucli oligopoly exists, whetlier the defendant possesses substantial market power independently.

\section{The Relevant Market}

Identification of the relevant market is necessary to determine the extent of a supplier's market power either as a core member of a tightly-knit oligopoly or independently. The concept of relevant inarket has not been fully articulated in territorial restrictions cases under the rule of reason, but it was utilized in several pre-Sylvania decisions, includimg $S c h w i n n,{ }^{103}$ and it has been referred to in a number of postSylvania section 1 cases. ${ }^{104}$ Furthermore, relevant narket definition is well-developed in other contexts, particularly monopolization cases under section 2 of the Sherman Act. ${ }^{105}$

The relevant inarket is defined on two levels. First, those products must be identified that are reasonably interchangeable with the defendant supplier's products "for the purposes for which they are produced-price, use and qualities considered." 106 This inquiry amounts to an assessment of the products' cross elasticities of demand-"the responsiveness of the sales of one product to price changes of the

market power that a defendant might possess independently. Although the inquiry here is directed toward the former purpose, it also provides the information necessary to fulfill the latter.

103. 388 U.S. at 381-82; Sandura Co. v. FTC, 339 F.2d at 880-83; Snap-On Tools Corp. v. FTC, 321 F.2d at 833 .

104. Lee Klinger Volkswagen, Inc. v. Chrysler Corp., 588 F.2d 910, 914-15 (7th Cir.), cert. denied, 439 U.S. 1004 (1978); Gough v. Rossmoor Corp., 585 F.2d 381, 385 (9th Cir. 1978), cert. denied, 439 U.S. 1004 (1979); Columbia Metal Culvert Co. v. Kaiser Alum. \& Chem. Corp., 579 F.2d 20, 26-27 (3d Cir.), cert. denied, 439 U.S. 876 (1978); Northwest Power Prods., Inc. v. Omark Indus., Inc., 576 F.2d 83, 85 (5th Cir. 1978), cert. denied, 439 U.S. 1116 (1979); Martin B. Glauser Dodge Co. v. Chrysler Corp., 570 F.2d at 81.

105. 15 U.S.C. $\$ 2$ (1976). See, e.g., United States v. Grinnell Corp., 384 U.S. 563, 571-77 (1960). In Columbia Metal Culvert, the court recognized the difference between the uses of the relevant market concept in $\S 2$ and $\S 1$ Sherman Act cases:

The $\S 2$ market definition looks to the existence of competitors as evidence of countervailing power which would preclude monopolization. $\S 1$, in contrast, is concerned with patterns of competition as a means of judging whether a restraint of trade is unreasonable. Thus, rival products might provide sufficient competition to foreclose a finding of monopolization, yet the degree of insularity of the initial product might allow a finding of illegal restraint of trade in regard to restrictions imposed within that mitial market. For instance, stifling intra-brand competition may violate $\S 1$, while "monopoly" over a given brand would clearly not run afoul of $\S 2$.

579 F,2d at 27 n.11.

106. United States v. E.I. du Pont de Nemours \& Co., 351 U.S. 377, 404 (1956). The Schwinn Court clearly adopts this standard: "[T] here is no showing that [other bicycles] are not in all respects reasonably interchangeable as articles of coinpetitive commerce with the Schwinn product." 388 U.S. at 381 (emphasis supphed). 
other."107 Such an assessinent is obviously difficult and involves substantial factual analysis. Furthermore, it is the subject of significant theoretical and inethodological controversies. ${ }^{108}$ In both Sherman Act and Clayton Act cases, however, ${ }^{109}$ courts have defined a set of operative criteria to assess cross elasticities of demand. Although too detailed to outline here, these criteria can be applied in the context of vertical restrictions.

The second level on which courts define relevant markets is geographic. The task is to determine "the area of effective competition" or the geographic area "to which the purchaser can practically turn for supplies."110 This level of mquiry is important because even though there may be many suppliers of a product nationwide, some or all of them might pose no serious competitive threat. For exainple, if a supplier is alone in a particular region, it nay increase prices up to the sum of the distributor price for alternative products and the cost of shipping them into the region. The fact that such alternatives exist may be irrelevant to the question of whether the suppher is subject to competitive pressures if such alternatives are far away.

\section{Industry Characteristics \\ a. Concentration}

Courts often look at the number and size distribution of firms in an industry to measure its competitive vitality. ${ }^{111}$ Economic theory suggests that, other things being equal, the degree of industry concentration is inversely related to the vigor of interbrand competition. ${ }^{112}$ Thus, as an industry becomes inore concentrated, the level of interbrand coinpetition diminishes until it disappears altogether when inonopoly is reached. ${ }^{113}$

107. United States v. E.I. du Pont de Nemours \& Co., 351 U.S. at 400 . Note that Grinnell has subsequently made the $d u$ Pont language equally applicable to services. 384 U.S. at 572-73.

108. 2 P. AReeda \& D. TuRner, Antitrust Law 19 517-29, 533-36 (1978); Day, Massy, \& Shocker, The Public Policy Context of the Relevant Market Question, in MARKETINo AND THE Public InTEREST 51-67 (J. Cady ed. 1978).

109. Exclusive dealing cases under $\S 3$ of the Clayton Act, 15 U.S.C. $\S 14$ (1976), and merger cases under $\$ 7$ of the Act, id. $\S 18$, also provide guidance in this area. See, e.g., Brown Sloe Co. v. United States, 370 U.S. 294, 325 (1962) (1nerger); Tampa Elec. Co. v. Nashville Coal Co., 365 U.S. 320, 327 (1967) (exclusive dealing).

110. Tampa Elec. Co. v. Nashville Coal Co., 365 U.S. at 327. For an implicit apphication of a similar definition in a monopolization case, see Grinnell, 384 U.S. at 575-76.

111. See, e.g., American Motor Inns, Inc. v. Holiday Inns, Inc., S21 F.2d 1230, 1247-48 (3d Cir. 1975); Sandura Co. v. FTC, 339 F.2d at 852.

112. F. SCHERER, supra note 21, at 50; Demsetz, Industry Structure, Market Rivalry and Public Policy, 16 J. L. \& Econ. 1 (1973); Esposito \& Esposito, Foreign Competition and Domestic Industry Profitability, 53 Rev. Econ. \& STAT. 343 (1971).

113. F. SCHERER, supra note 21, at 10; Saving, Concentration Ratios and the Degree of Monopoly Power, 11 INT'L ECON. REv. 139 (1970). 
An industry may be said to be oligopolistic when there are few enough sellers that eacli supplies enough of the total market output to influence market price with output adjustments and will thus anticipate reactions by its rivals to its output and price adjustments. ${ }^{114}$ The level of concentration which will result in oligopoly may, of course, vary, but some guidelines exist. Thus, a market will not be considered a tightly $k$ nit oligopoly unless four firms account for more than fifty percent of industry sales. ${ }^{115}$

\section{b. Product Differentiation}

In addition to the level of concentration just described, substantial product differentiation must exist within the relevant market before a court can characterize a group of suppliers as a tightly knit oligopoly. ${ }^{116}$ Professor Cliamberlin, the first economist to explore the subject of product differentiation fully, observed that:

A general class of product is differentiated if any significant basis exists for distinguishing the goods of one seller from those of another. Such a basis may be real or fancied, so long as it is of any importance whatever to buyers and leads to a preference for one variety of the product over another. Where such differentiation exists, even though it be sliglit, buyers will be paired with sellers, not by chance and at randoin but according to their preferences. ${ }^{117}$

Thus, the degree of product differentiation refers to the extent to which "buyers differentiate, distimguish, or have specific preferences among the competing outputs of the various sellers established in an industry." 118

A supplier witl a well-differentiated product or brand faces a less price-elastic demand curve than a supplier whose product is imdistimguishable from those of its competitors. That is, a price increase will cause fewer consumers to seek substitutes for a product when the supplier lias made that product appear qualitatively different from others than when all competing products appear interchangeable. ${ }^{119}$

It las been observed that a high degree of product differentiation in a market will usually lead to, or be associated with, high seller con-

114. J. Bain, Industrial Organization $28-29$ (2d ed. 1968); W. Shepard, The Economics of Industrial Organization 63 (1979); L. Stern \& J. Grabner, JR., Competition in the MARKETPLACE 40-46 (1970).

115. Id.

116. $I d$.

117. E. Chamberlin, The Theory of Monopolistic Competition 56 (7th ed. 1958).

118. J. BAIN, supra note 114 , at 223.

119. F. Scherer, supra note 21, at 341; Brozen, Entry Barriers: Advertising and Product Differentiation, in Industrial Concentration: The New Learning $117 \mathrm{c}$. Goldschmid, $\mathrm{H}$. Mann, \& J. Weston eds. 1974) [hereinafter cited as InDUSTRIAL ConCENTRATION]; Pitofsky, supra note 12 , at 37 . 
centration. ${ }^{120}$ It therefore follows that the higher the level of product differentiation in a market, the less prevalent will be intense imterbrand competition, especially price competition, and the more important will be intrabrand competition.

\section{c. Entry Barriers}

Finally, barriers to entry into the relevant market are important in determining whether a tightly knit oligopoly exists. ${ }^{121}$ Such barriers reduce the threat of competition from new and future suppliers. In effect, they are the advantages established sellers have over potential rivals. Theoretically, they permit an established supplier to charge prices that yield a greater-than-normal rate of return on investment without attracting new competitors.

Economic characteristics of the production and distribution process such as scalar economies and absolute cost barriers create the most common entry barriers. ${ }^{122}$ Other forces, however, may also create barriers. For example, a firm may have so successfully differentiated its brand through advertising that any potential competitor must spend substantial sums at the outset just to convince consumers that its product is a viable substitute for the established brand.

Other things being equal, one would expect the level of interbrand competition to correlate negatively with the height of entry barriers. That is, the threat of new suppliers entering the market is a competitive force, so that when high entry barriers diminish that threat, one would expect the general level of interbrand competition to fall as well. When this occurs, the importance of intrabrand competition is, of course, increased.

In summary, if concentration, product differentiation, and entry barriers in the relevant market are all high, the extent of interbrand competition is likely to be low, and there will be strong potential benefits from preserving intrabrand competition. More specifically, if the concentration level is such that four firms command fifty percent of the relevant inarket and the other two factors are present, a tightly knit oligopoly exists. ${ }^{123}$ If the defendant supplier is one of the four largest firms, any vertical nonprice restrictions that it imposes should be presumed to be illegal.

120. J. BAIN, supra note 114 , at 249 . It has been further observed that vertical restraints may increase product differentiation. Bohling, supra note 73, at 506.

121. See note 114 supra.

122. L. StERn \& J. GRABNER, JR., supra note 114, at 24-25.

123. See note 114 supra. 


\section{Market Power}

Courts have frequently mentioned and apphed a supplier's market dominance as a criterion for judging the reasonableness of territorial restrictions. ${ }^{124}$ This is, of course, because market share is generally considered to be a leading indicator of market power, and for the reasons discussed above, ${ }^{125}$ intrabrand counpetition is most important when suppliers have substantial market power.

The courts have declined, however, to establish a bright-line standard to indicate how great a suppher's market share must be before the restrictions at issue should be considered unreasonable. ${ }^{126} \mathrm{Al}-$ though their reluctance to proinulgate such a standard is certainly due in part to a need to preserve flexibility, it also indicates their recognition that other factors affect the significance of market share in assessing market power. ${ }^{127}$ Perhaps unost important are the number and size of the other firms in the industry. For example, a ten percent inarket share may confer a great deal of power in a severely fragmented industry where there are numerous other suppliers, none of which has a market share even remotely comparable to that held by the largest firm. In such a situation, prices lower than those charged by the "dominant" firm would have no appreciable effect on that firm's sales, while prices set higher than those of the "dominant" firm would have a significant negative effect on the smaller firms' sales. On the other hand, a ten percent market share in an industry in which only three firms hold the other ninety percent may confer relatively little market power. Thus, courts unust examine the concentration of the industry as a whole as well as the defendant supplier's place in the industry in order to detect market power. ${ }^{128}$

124. E.g., United States v. Topco Assocs., Inc., 405 U.S. at 622-23 (Burger, C.J., dissenting); United States v. Arnold, Schwinn \& Co., 388 U.S. at 374-75, 381; United States v. Sealy, Inc., 388 U.S. at 361 \& n.2 (Harlan, J., dissenting); American Inns, Inc. v, Holiday Inns, Inc., 521 F.2d at 1247-48; Newberry v. Washington Post Co., 438 F. Supp. at 474-75.

In fact, in his concurrence in Sylvania, Justice White stated that market power is chiefly dependent on the supplier's market share, the extent to which the suppher's product is differentiated, or both of these factors. 433 U.S. at 64 (White, J., concurring) (citing F. SCHERER, supro note 21 , at 10 ).

125. See notes $98-101$ and accoinpanying text supro.

126. ABA MonOGRAPH, supra note 12, at 63-64 (footnote omitted).

127. For example, in a post-Sylvania case, Newberry v. Washington Post Co., 438 F. Supp. 471 (D.D.C. 1977), the defendant newspaper had a de facto monopoly in its relevant market. However, territorial and customer restrictions developed by a course of conduct were upheld on the grounds that the Post's dominant status was lawfully attained and the restrictions were necessary to distribute the paper properly. Id. at 474-77.

128. Scherer has indicated that dominant firm price leadership occurs "when an industry consists of one firm dominant im the customary sense of the word-i.e., controlling at least 50 percent of the total industry output-plus a 'competitive fringe' of firms, each too small to exert a perceptible influence on price through its individual output decisions." F. ScHERER, supra note 21, at 165. 
Courts must also consider product differentiation. If a supplier succeeds im differentiating its product, it may make the demand for that product relatively price-inelastic. Under sucl1 a condition, the reduction im the quantity demanded resulting from a price increase will be so sinall as to be more than offset by the increase in revenue from eacli unit sold. As a result, total revenue may be increased by raising prices. ${ }^{129}$ This obviously constitutes power over price. Otlier things being equal, the greater the degree of differentiation, the greater the power over price.

These two characteristics of the defendant supplier-share of the relevant market relative to the shares of other firms and product differentiation-indicate whether a defendant supplier possesses substantial market power. If a court finds that a defendant has substantial market power, it should presunie that any vertical territorial or customer restrictions the defendant has imposed are illegal.

\section{Rebutting the Presumption}

The presumption of illegality raised on the basis of structural analysis may not always be appropriate. In certain rare cases, the defendant can justify vertical restrictions under the rule of reason even though they may not increase interbrand competition. The presuinption may be rebutted in the following circuinstances: (1) where the defendant supplier is failing or at least faltering; or (2) wliere forbidding the restrictions would frustrate extracompetitive interests suclı as product safety and quality and broader societal goals and pohicies.

\section{a. Failing or Faltering Companies}

A firm nay find itself in serious financial trouble even if it has market power. Furthermore, the failure of such a firm may diminish interbrand coinpetition in the long run. When vertical restrictions are necessary im order to prevent a menber of the oligopolistic core of an industry from leaving the market, courts should find that the defendant supplier has rebutted the presumption that those restrictions are illegal. $^{130}$

Such a market structure, however, could be considered ohgopolistic. Our inquiry at this point should not be limited to oligopolies, but should seek to identify substantial market power in all settings. Thus, courts should examine all firms that have large market shares relative to their competitors, even in atomistic or monopolistically coinpetitive markets.

129. R. Posner, ANtitrust CASes, Economic Notes and Other Materials 49 (1974).

130. Courts and commentators have argued that short-term intrabrand competition can be sacrificed in the name of long-term interbrand competition where the supplier is failing. See, e.g., United States v. Arnold, Schwinn \& Co., 388 U.S. at 374-75, 379-80; Louis, supra note 29, at 293; Pitofsky, supra note 12, at 29 n.85, 35. However, no decision has ever upheld such a defense. ABA MONOGRAPH, supra note 12 , at 16 . The Sylvania majority may lave indicated that the issue 
This point inay be illustrated with the case of the Chrysler Corporation. That company commands a relatively large share of the domestic automobile market. Barriers to entry are sufficiently high, and Chrysler has so differentiated its products from those of its competitors that it is in a position to affect prices in the market. Nonetheless, it experienced large losses in the summer and fall of $1979 .{ }^{131}$

In the automobile industry, an active dealer network is essential. To ensure an effective network, Chrysler has imposed location and other restrictions on its dealers. Chrysler's current financial difficulties, however, could quite conceivably erode its network and thus hasten its demise. Chrysler's competitors may persuade a number of important dealers to seek a more secure supplier, or, at a minimum, to devote fewer promotional resources to Chrysler products and more to other brands or products. Thus, Chrysler may be able to justify its existing restrictions-indeed, perhaps even stronger restrictions such as exclusive territories-with the rationale that they are necessary to mamtain the strong dealer loyalty and promotion essential to its survival.

In addition to causing dislocations in the labor and materials markets, the failure of Chrysler Corporation would have serious anticompetitive effects in the automobile industry. Chrysler's withdrawal from the oligopolistic core of the industry would strengthen the already powerful positions of the remaining firms.

In Chrysler's case, the structural characteristics of the industry might trigger the presumption that its vertical restrictions are illegal. These restrictions, however, might help keep Chrysler viable and thus could actually prevent an occurrence that would have profound anticompetitive effects. Therefore, a court should find that Chrysler has rebutted the presumption that, as a nember of an oligopolistic core, its vertical restrictions are illegal, since striking them down without further examination may result in a long-term reduction in interbrand competition.

is not worthy of separate or special consideration, 433 U.S. at $58 \mathrm{n} .29$, but Justice White's concurrence extended the principle to include a "faltering" firm, like Sylvania, which was "a . . . manufacturer with a 'precarious' position in a generic product inarket dominated by another firm." Id. at 65.

131. Chrysler is not a failing company as that term has been used in the merger context. That definition requires, inter alia, that the resources of the troubled firm be so depleted and the prospect of rehabilitation so remote that it faces the distinct likelihood of bankruptcy from which it cannot be reconstituted. See Citizen Publishing Co. v. Umited States, 394 U.S. 131 (1969). But see United States v. General Dynamics Corp., 415 U.S. 486 (1974); United States v. International Harvester Co., 564 F.2d 769 (7th Cir. 1977). Rather, it is what we will call a "faltering" company similar to that in Sandura Co. v. FTC, 339 F.2d 847 (6th Cir. 1964). That is, we adopt the language of Justice White in his Sylvania concurrence: "a [firm] with a 'precarious' position in a generic product market dominated by another firm" or other firms. 433 U.S. at 65 . 


\section{b. Extracompetitive Justifications}

There is a continuing controversy about whether social benefits not related to market structure nay, under the rule of reason, justify restraints on coinpetition. ${ }^{132}$ The debate centers on the goals that underlie the antitrust laws ${ }^{133}$ and whether, in particular cases, courts should subordinate those goals to other, noneconomic social objectives. The concern is that consideration of extracompetitive factors could validate an anticompetitive restraint or condemn a procompetitive arrangeinent.

Competition is clearly the primary objective of the antitrust laws. ${ }^{134}$ Some maintain, however, that courts should also consider social goals not directly related to competition. ${ }^{135}$ Two Sherman Act cases-Chicago Board of Trade v. United States ${ }^{136}$ and Appalachian Coals, Inc. v. United States ${ }^{137}$ - provide some support for the latter view.

More recent cases, however, seem to bear out Professor Sullivan's stateinent that "[c]ourts are loath to accept a ministerial discretion to decide when a trade has purchased the right to restrict competition by proffering other social gains." 138 In National Society of Professional Engineers $v$. United States, ${ }^{139}$ the Court struck down a prohibition on competitive bidding proinulgated by a professional group as violative of the Sherman Act. The group sought to justify the proscription on the ground that its purpose was to minimize the risk that competition would produce inferior engineermg work to the detriment of public safety. The Court rejected this argument without considering its factual basis.

Emphasizing that competition is the primary focus of the Sherman

132. Compare, e.g., Pitofsky, The Political Content of Antitust, 127 U. PA. L. REV. 1051 (1979) with, e.g., Posner, supra note 12.

133. For a discussion of those goals, see Bohling, supra note 73, at 471-73.

134. In Northern Pac. Ry. v. United States, the Court stated:

The Sherman Act was designed to be a comprehensive charter of economic liberty aimed at preserving free and unfettered competition as the rule of trade. It rests on the premise that the unrestrained interaction of competitive forces will yield the best allocation of our economic resources, the lowest prices, the highest quahty and the greatest material progress, while at the same time providing an environment conducive to the preservation of our democratic political and social institutions.

356 U.S. at 4. See Posner, supra note 12, at 13-16.

135. See ABA MONOGRAPH, supra note 12, at 27-29 and the sources cited therein. As pointed out by Pitofsky, these contrasting viewpoints are manifested in Sylvania by tension between the najority opimion and Justice White's concurrence. Pitofsky, supra note 12, at 3 n.7.

136. 246 U.S. 231 (1918).

137. 288 U.S. 344 (1933). See also L. Sullivan, HaNdBook of the LAw of ANTITRUST 171-87 (1977).

138. L. Sullivan, supra note 137 , at 332.

139. 435 U.S. 679 (1978). 
Act, the Court noted that price competition in the initial selection of an engineer was effectively precluded by the antibidding policy. ${ }^{140}$ The defendant asserted that the interest in public safety could supplant competition. The Court found this notion wholly unacceptable, stating that "the Rule of Reason does not support a defense based on the assumption that competition is unreasonable."141

The significance of the decision to this Article does not turn on the case itself, for it involved what was essentially a horizontal conspiracy to avoid price competition rather than a system of vertical restraints. Instead, our concern hes with dicta in which the Court, citmg Tripoli Corp. v. Wella Corp. ${ }^{142}$ stated that restraints designed to promote product safety can be approved as long as "they have no anticompetitive effect and ... they are reasonably ancillary to the seller's main purpose of protecting the public from harm or itself froin product hability." 143

Tripoli does not, however, stand squarely for the proposition that vertical restrictions may be justified on product safety grounds only when there is no anticompetitive effect. Although the customer restrictions in that case appeared to have no interbrand anticoinpetitive intpact, they operated to obviate intrabrand competition between, on the one hand, wholesalers like Tripoli which sold Wella "professional" hair care products directly to the public as well as to professionals, and on the other hand, professionals who both sold and applied such products. ${ }^{144}$

Furthermore, aside from the factual differences between the two cases, an expansive reading of Professional Engineers is inconsistent with the tone of the Sylvania passage it cited. According to the Sylvania Court:

Marketing efficiency is not the only reason for a manufacturer's desire to exert control over the manner in which his products are sold and serviced. As a result of statutory and common-law developments, society increasingly deinands that inanufacturers assume direct responsibility for the safety and quahty of their products . . . . The legitinnacy of these concerns has been recognized in cases involving vertical restrictions. ${ }^{145}$

140. Id. at 692-96.

141. Id. at 696 .

142. 425 F.2d 932 (3d Cir. 1970).

143. 435 U.S. at 696 n.22.

144. The court's discussion of intrabrand anticompetitive effect was limited to competition between those distributors who sold to professionals. 425 F.2d at 939 .

145. 435 U.S. at $55 \mathrm{n} .23$ (citation to Tripoli omitted). One commentator has argued that Sylvania departs from the "efficiency is the sole goal of antitrust" approach. Bohling, supra note 73, at 497 .

Nevertheless, the Court's dicta in Professional Engineers may foretell the eventual repudia- 
Under Tripoli, then, where a product has significant potential for physical harm if improperly distributed, suppliers may restrict sales in a manner that will decrease the chance of user injury. ${ }^{146}$ Restraints designed to ensure that products receive the special handling necessary to preserve quality should similarly be considered reasonable. For example, customer restramts mtended to make sure that nonpasteurized beer is properly refrigerated, house plants are given proper ligliting, and interconnection is properly controlled in the shipment of farm machinery might be justified on product quality grounds.

In at least one case under the Schwinn doctrime, such a justification was disregarded. ${ }^{147}$ Smce Sylvania, lowever, it has become a proper factor; ${ }^{148}$ courts have recognized that defective and low-quality products are not in the consumer's best imterest. The cases suggest that im order for this justification to be considered, the product involved should be subject to some significant change if not properly cared for, and the restrictions imposed must clearly reduce the chances of such a change. ${ }^{149}$

Judicial recognition of product safety and quality as interests that may prevail over the antitrust policy of preserving intrabrand competition should open the door to recognition of otler, similar interests. Environmental or energy-saving goals may, im certain contexts, be sufficiently important to overcome the presumption agaimst restrictions imposed by suppliers with market power. For example, there may be substantial environmental reasons for encouraging the use of returnable rather than disposable soft drink and beer bottles. ${ }^{150}$ Returnables are feasible only if bottlers mamtam efficient systems for reclaiming them frown consumers. High-volume "discount" or "cream-skimming" bottlers, however, may attempt to sell over broad areas and count on local, "full service" bottlers to bear the burdens of collection. Thus

tion of some of what this Article has argued should be available to rebut the presumption of illegality. Since the issue is far from settled, we will retain our discussion of these points.

146. See generally Pitofsky, supra note 12, at 23-25.

147. Del Rio Distrib., Inc. v. Adolph Coors Co., 589 F.2d 176, 179 (5th Cir.), cert. denied, 48 U.S.L.W. 3191 (Oct. 2, 1979); Adolph Coors Co. v. FTC, 497 F.2d 1178, 1186-87 (10th Cir. 1974), cert. denied, 419 U.S. 1105 (1975).

148. Adolph Coors Co. v. A\&S Wholesalers, 561 F.2d 807, 813-14 (10th Cir. 1977).

149. For a post-Professional Engineers case that upholds safety and quality considerations under the rule of reason, see Clairol, Inc. v. Boston Discount Ceuter of Berkeley, Inc., 608 F.2d 1114 (6th Cir. 1979). See generally Dehydrating Process Co. v. A.O. Smith Corp., 292 F.2d 653 (Ist Cir.), cert. denied, 368 U.S. 931 (1961); United States v. Jerrold Elec. Corp., 187 F. Supp. 545 (E.D. Pa. 1960), affd per curiam, 365 U.S. 567 (1961); Pitofsky, supra note 12, at 23-25.

150. In fact, two environmental concerns may be involved. One is the problem of litter, especially in those cases where jurisdictions have not passed so-called "bottle bills" which require deposits on nonrefillable soft drink and other beverage containers. The other is the problem of material waste associated with an inability to reuse the containers, except through an expensive recycling process. 
overburdened, local bottlers may explicitly refuse or implicitly discourage returns. To prevent the destructive results of sucl1 "free riding," territorial restrictions may arguably be justifiable. ${ }^{151}$

The extension of Tripoli's logic to environmental and other social concerns is untested in the courts. Certainly, the impact of any social or environmental issue must be great to justify overriding competitive and efficiency goals. Where an important social imterest is at stake, the court should be willing to balance this interest against cconomic interests. Professional Engineers need not be read to rigidly prohibit such judicial inquiry.

\section{c. The Effect of Rebuttal}

If a defendant supplier demonstrates either that it is faltering or that its vertical restrictions effectively serve an important, societal interest, the court should not consider those restrictions illegal at this point. This does not mean, however, that the restraints may not in the end be found unreasonable. The rebuttal contemplated in this step establishes only that a structural analysis of the defendant's position in the relevant market is inadequate to foreclose further inquiry; it is merely a prima facie slowing of reasonableness. ${ }^{152}$

\section{Summary}

A showing by the plaimtiff that the defendant is a core nember of a tightly knit oligopoly or otherwise has substantial market power triggers the presumption that its vertical restrictions are illegal. If the defendant successfully rebuts the presumption, the court shonld proceed to Step Five. If, however, the presumption goes unrebutted, the court should declare the restriction illegal without furtler analysis. Finally, if the defendant is not a core member of a tightly knit oligopoly and does not possess substantial market power, the court shonld proceed to Step Five.

\section{E. Step Five: Offsetting Benefits to Interbrand Competition}

If, in the preceding step, the defendant rebuts the presumption that its restrictions are illegal or the plaintiff fails to show that the presumption should be raised at all, the court inust next determine whether the restrictions at issue lave had or are likely to have a positive effect on

151. See generally Coca-Cola Co., 91 F.T.C. 517, appeal docketed, No. 78-1364 (D.C. Cir. 1978); Pepsi Co., Inc., 91 F.T.C. 680 (1978), appeal docketed, No. 78-1545 (D.C. Cir. 1978).

152. The plaintiff still bears the burden of proving such restraints unreasonable. See generally Magnus Petroleuin Co. v. Skelly Oil Co., 599 F.2d 196, 204 (7th Cir. 1979); Northwest Power Prods., Inc. v. Omark Indus., Inc., 576 F.2d at 90. 
interbrand coinpetition in the relevant market. ${ }^{153}$ More specifically, the inquiry is whether the restrictions are necessary to allow the suppher to compete inore effectively with other supphers.

This is necessarily a conjectural undertaking. It will begin with analysis of the defendant's explanation of the restriction's economic purposes. The court inust obviously view such self-serving statements circumspectly. ${ }^{154}$ Nevertheless, the explanations do focus the court's attention on specific characteristics of the market. ${ }^{155}$ After the defendant has explained the restriction's alleged benefits, the court must determine whether the restriction is reasonably necessary to achieve the contemplated objective. ${ }^{156}$ A restriction that goes beyond the supplier's needs not only suggests the existence of a less harmful alternative, but also invites the suspicion that the real purpose of the restriction is anticompetitive. ${ }^{157}$

\section{Procompetitive Purposes}

There are countless methods to distribute the wide variety of goods and services available to American consumers. Supphers may therefore assert various ways in which vertical restrictions will make their distribution systems more effective. This section will discuss three recognized justifications for such restraints: to induce imvestinent, to

153. See, e.g., Catalano, Inc. v. Target Sales, Inc., 605 F.2d 1097, 1100 (9th Cir. 1979) (citing L. SULLIVAN, supra note 137 , at 280 ).

154. One commentator has noted that "[t]he primary problem with evidence of purpose-to put the matter bluntly-is that in modern antitrust cases, such evidence will often reflect what counsel advise busmessmen their purpose should have been." Pitofsky, supra note 12, at 35. See also Louis, supra note 29 , at 280.

155. As Justice Brandeis stated in Chieago Board of Trade, "[K]nowledge of the intent may help the court to interpret facts and to predict consequences." 246 U.S. at 238. See White Motor Co. v. United States, 372 U.S. at 259-64; Kestenbaum v. Falstaff Brewing Corp., 575 F.2d at 573; Martin B. Glauser Dodge Co. v. Chrysler Corp., 570 F.2d at 82-83.

Without anticompetitive effect, unlawful intent will not establish a rule of reason violation. See, e.g., H\&B Equip. Co. v. International Harvester Co., 577 F.2d at 246; Northwest Power Prods., Inc. v. Omark Indus., Inc., 576 F.2d at 90 . At the same time, while essentially self-serving conduct may produce procompetitive outcomes, economic self-imterest without this result is not enough to permit restraint of trade. See, e.g., United States v. Arnold, Schwinn \& Co., 388 U.S. at 375; Heclit v. Pro-Football, Inc., 570 F.2d 982, 996 (D.C. Cir. 1977), cert. denied, 436 U.S. 956 (1978).

156. See United States v. Arnold, Schwinn \& Co., 388 U.S. at 380-81; American Motor Inns, Inc., v. Holiday Inns, Inc., 521 F.2d at 1248-49; Munters Corp. v. Burgess Indus., Inc., 450 F. Supp. 1195, 1209-11 (S.D.N.Y. 1978); Newberry v. Washington Post Co., 438 F. Supp. at 475; Pitofsky, supra note 12, at 36-37; Posner, supra note 12, at 11-12.

Several courts and commentators have argued that a least restrictive alternative test should apply, see, e.g., Copper Liquor, Inc. v. Adolph Coors Co., 506 F.2d at 947; Sandura Co. v. FTC, 339 F.2d at 856; ABA MONOGRAPH, supra note 12, at $58 \mathrm{n} .229,59 \mathrm{n} .233$, but the better view is that the existence of less restrictive alternatives is relevant but not determinative. See, e.g., White Motor Co. v. United States, 372 U.S. at 271 (Brennan, J., concurring); American Motor Inns, Inc. v. Holiday Inns, Inc. 521 F.2d at 1248-50; Snap-On Tools Corp. v. FTC, 321 F.2d at 832.

157. See White Motor Co. v. United States, 372 U.S. at 270 n.9 (Brennan, J., concurring). 
improve market coverage, and to stimulate supportive activities. Courts must examine closely the structure and practices of the particular market in which the restraint is imposed to assess these justifications.

\section{a. Inducing Investment}

The handling of certain products or services may require a substantial initial investment by the distributor. In deciding whether to undertake such an investment, a potential distributor will obviously evaluate the risks involved. If a product is new or if it is established but has recently experienced declining sales, the risk to the distributor of making or maintaining an investment in the product may appear greater than that associated with other brands.

To attract or retain high quality distributors, a new entrant or faltering supplier may thus find it necessary to offer special incentives. The insulation of distributors through vertical restrictions from certam types of imtrabrand competition nay provide the necessary impetus to investment by increasing or making more secure the distributors' revenues. ${ }^{158}$ Courts have widely recognized that territorial restraints are useful or even crucial in helping a supplier to obtain a market presence $^{159}$ or maintain one. ${ }^{160}$

\section{b. Improving Market Coverage}

An establislied firm may find that it can expand its market coverage by imposing vertical restrictions. Unregulated intrabrand competition may cause distributors to direct all of their energies to attracting the business of a few, high-profit, "cream" buyers and neglect less prof-

158. See Louis, supra note 29 , at 296-99. According to the author, this point is supported by the virtual per se legality of exclusive franchises. Id. at 286-87. See note 29 supra.

159. Continental T.V., Inc. v. GTE Sylvania Inc., 433 U.S. at 55; White Motor Co. v. United States, 372 U.S. at 263; id. at 269 (Brennan, J., concurring); United States v. Topco Assocs., lnc., 319 F. Supp. at 1043. See also ABA MoNoGRAPH, supra note 12, at 68-69; Louis, supra note 29, at 296-99; Preston, supra note 15, at 511.

160. White Motor Co. v. United States, 372 U.S. at 263; Sandura Co. v. FTC, 339 F.2d at 857; Snap-On Tools Corp. v. FTC, 321 F.2d at 832; Newberry v. Washington Post Co., 438 F. Supp. at 475.

Soine commentators argue that territorial inducements are unnecessary and that natural market forces ought to be allowed to channel resources into those opportunities that represent the best investunents. E.g., Comanor, supra note 28, at 1429; Pitofsky, supra note 12, at 18-19; Hearings on S. 2548 Before the Subcomm. on Antitrust \& Monopoly of the Senate Judiciary Comm, 89th Cong., 2d Sess. 1088 (1966) (Statement of Donald F. Turner) [hereinafter cited as 1966 Hearings]. This contention may have soine merit in certain limited cases, such as those in which suppliers have market power and command exceptionally high profits which would naturally attract economic resources. More often, however, prospective supphers and their distributors face significant entry barriers created by such factors as concentration in the market, substantial product differentiation, and entrenclied brand loyalty. 
itable accounts. If, however, a suppher divides the "cream" accounts evenly among its distributors and enforces that division with territorial restraints, each distributor may give more attention to the less profitable buyers in its territory. ${ }^{161}$ A federal district court accepted this justification for vertical restraints in Newberry v. Washington Post Co. ${ }^{162}$

\section{c. Stimulating Supportive Activity}

The point of sale is often the most efficient level at which to provide supportive activities-promotion, repairs, and customer service. However, the free-rider effect inay discourage point-of-sale provision of such activities. ${ }^{163}$ For example, a distributor that provides advertising and showrooins may discover that consuners take advantage of its services and then make their purchases froin another distributor-a free rider-that does not provide any services but offers the product at a lower price. ${ }^{164}$ Confronted with such consumer behavior, distributors may all decide to lower their service levels, despite the suppher's msistence that such amenities are necessary to interbrand competition. ${ }^{165}$

A supplier may assert that vertical restraints are necessary to combat this problem. As a quid pro quo for providing ancillary services, 68.

161. Preston, supra note 15, at 511-19. See also ABA MonogRAPH, supra note 12 , at $40,67-$

162. 438 F. Supp. 471,475 (D.D.C. 1977).

163. R. PosNER, supra note 22. For exanple, a consumer shopping for cameras may prefer to go to a full-service photographic retailer to learn about the features of various cameras and then, armed with the information provided, purchase the desired camera at the lowest available price at a nonservice outlet (e.g., a discount store or a catalog showroom). Thus, the nonservice retailer has taken a "free ride" on the efforts of the other seller. In the long run, the full-service distributor may refuse to provide information for cameras being sold at nonservice outlets, discontinue selling the items in question, or attempt to switch the consumer to itens where intrabrand competition is controlled.

To avoid this result and to encourage provision of distributor services, the supplier seeks to impede intrabrand competition with vertical restraints so that its distributors can charge a price that will support the level of services desired by the supplier. As Professor Posner has observed, a distributor operating under a system of vertical restrictions "will provide that level of services [required by the supplier] rather than pocket the difference between the high price and the cost of distribution with little service because, if he does not, the [supplier] will reassign the territory to another dealer." Id.

The higher profits accruing to the dealer induce it to mcrease expenditures on services until those profits are competed away through service competition. The end result is that the supplier achieves greater sales volume because consumers receive the services they demand from the dealers, while the dealers' profits are held to reasonable levels.

164. These are essentially the facts of National Auto Brokers Corp. v. General Motors Corp., 572 F.2d 953 (2d Cir. 1978), cert. denied, 99 S.Ct. 3069 (1979), where a broker and its franchisees sued General Motors and soine of its franchised dealers alleging a conspiracy to boycott the broker system. See United States v. General Motors Corp., 384 U.S. 127 (1966) (boycott of discounters). See also Blackwelder Furmiture Co. v. Seilig Mfg. Co., 550 F.2d 189 (4th Cir. 1977) (prior to termination, North Carolina furniture distributor sold to mail-order customers im Washington, D.C. as much as $30 \%$ below manufacturer's suggested prices).

165. See note 163 supra. 
the supplier protects its distributors from free riders by imposing territorial restramts. ${ }^{166}$

\section{Restraint Universality}

Proof that vertical restrictions are necessary to increase a supplier's competitive effectiveness in one or more of the three ways just discussed may be madequate to show that those restrictions have a positive effect on interbrand competition. When all of the suppliers im an industry impose similar restrictions on a standard basis, the restrictions inay actually impair such competition. The restrictions may inake pricing behavior nore obvious and predictable because they reduce the total number of competing sellers. Consequently, even though the restrictions improve each supplier's effectiveness in distributimg goods, they may permit suppliers to behave as oligopolists. Thus, the more prevalent a particular restriction is, the less likely that the defendant's application of it promotes competition.

There is an exception to this principle. Vertical restrictions imposed by either new or failing firms should be considered proconpetitive if the firms would be unable to penetrate or remam in the inarket without the restraints. Forbidding the restraints in either situation would reduce the number of competitors and therefore impair interbrand competition.

If these inquiries suggest that the restrictions do not positively affect interbrand competition, a court should presume that the restrictions are illegal. This second presurnption should have the same effect as the first presumption raised in Step Four and should be rebuttable on the same showing.

Thus, if the restrictions liave a positive effect on interbrand competition or if the second presumption is rebutted here, the court should declare the restrictions legal. If, however, the restrictions do not im-

166. This method of dealing with the free-rider problem has been criticized in the commentary. The most extreme attack comes from Comanor who maintains that the free-rider effect is merely an excuse to amass market power through the differentiative activities encouraged by excessive distributor markups. Comanor, supra note 28, at 1429-30. The solution, he maintains, is to let the market determine which services should be offered, rather than packaging products and services togcther. Id. Others do not go so far. They recognize that the free-rider justification for imposing vertical restrictions may be valid in some limited instances, but note that not all industries or products are prone to free riders. E.g., Pitofsky, supra note 12, at 23; The Supreme Court, supra note 12 , at 236 . They also point out that free riders may be eliminated in a less restrictive fashion by offering the desired services at separate cost or by inanufacturer subsidization of supportive activity. Pitofsky, supra note 12, at 21-23. Pitofsky goes on to question whether the additional profits facilitated by vertical restraints will be used to provide the level of services desired by the suppher. Id. Posner, on the other hand, has no such doubts; he maintains that distributors will furnish such services rather than pocket additional profits because they fear that they will be replaced by the supplier if they do not. See note 163 supra. 
prove interbrand competition or the defendant does not rebut the second presumption, the court should declare the restrictions illegal.

\section{CONCLUSION}

Sylvania requires that a rule of reason standard be applied to evaluate vertically imposed restraints. The purpose of such a standard is to balance intrabrand agamst interbrand coinpetitive effects. ${ }^{167}$ So far, however, courts have failed to establish an analytic frainework with which to judge those restraimts.

This Article presented a rule of reason framework based on establislred antitrust precedents and economic principles. The framework is designed to assist both the bench and bar $m$ assessing vertical restraints im the particular context in which they are found. The Steps in the inodel can be summarized as follows:

1. Identify the agreeinent: if the restriction is not the product of an agreement between a supplier and its distributors, it is valid.

2. Apply a per se rule if there is evidence of horizontal conspiracy or price fixing.

3. Assess the negative impact on intrabrand competition: if the restriction does not significantly inhibit a distributor in its attempts to win customers away from other distributors of the same brand, it is valid and the analysis ends.

4. Determine whether the restrictions are presumptively illegal: if the defendant supplier is a core nnember of a tightly knit oligopoly or otherwise possesses substantial market power, the presumption is raised; if not, proceed to Step Five.

a. Define the relevant market:

i. Product market;

ii. Geographic market.

b. Examine the following characteristics of the market to detect a tightly knit oligopoly or to aid in assessing defendant's market power absent suclı an oligopoly:

i. Industry concentration;

ii. Product differentiation;

iii. Entry barriers.

167. See 433 U.S. at 57 n.27. See also United States v. Arnold, Schwinn \& Co., 388 U.S. at 374, 382; White Motor Co. v. United States, 372 U.S. at 266 n.3 (Brennan, J., concurring); Martin B. Glauser Dodge Co. v. Chrysler Corp., 570 F.2d at 82; Elfman Motors, Inc. v. Chrysler Corp., 1977-2 Trade Cas. ๆ 61,650 at 72,683 (E.D. Pa. 1977); United States v. Topco Assocs., Inc., 319 F. Supp. at 1043.

Although this model does not explicitly strike a single, final balance, it weighs the various coinpetitive effects at each step by identifying factors that may make the restraint per se legal or illegal and by erecting presumptions of illegality. 
c. If defendant is not a core member of a tightly knit ohgopoly, assess its market power.

d. Determine whether the presumption of illegahty, if raised, may be rebutted; if so, proceed to Step Five.

i. Defendant is a failing or faltering company;

ii. Extracompetitive interests are served by the restrictions:

(A) Product safety or quality;

(B) Broad societal goals and policies.

5. Determine whether the restrictions have a positive effect on interbrand competition; if they do not, a presumption of illegahty similar to that in Step Four is raised; if they do, proceed to Step Five.

a. Determine whether the restrictions have one of the following procompetitive purposes:

i. Inducing imvestment;

ii. Improving market coverage;

iii. Stimulating supportive activity.

b. Determine whether, despite a procompetitive purpose, universality of the restraints make their effect anticonpetitive.

c. If the restrictions do not have a positive effect on interbrand competition, determine whether the presumption of illegality thus raised may be rebutted in the ways described in Step Four. 